\title{
Recent Trends in Theory Use and Application within the Project Management Discipline
}

\author{
Nathan Johnson ${ }^{1}$, Todd Creasy ${ }^{2}$, and Yang Fan ${ }^{3}$ \\ ${ }^{1}$ Assistant Professor, School of Economics, Management \& Project Management, Western Carolina University, \\ 104 Forsyth, Cullowhee, NC, 28723. E-mail: nathan.johnson@wcu.edu (corresponding author). \\ ${ }^{2}$ Associate Professor, School of Economics, Management \& Project Management, Western Carolina University, \\ 104 Forsyth, Cullowhee, NC, 28723. E-mail: rtcreasy@email.wcu.edu \\ ${ }^{3}$ Associate Professor, School of Economics, Management \& Project Management, Western Carolina University, \\ 104 Forsyth, Cullowhee, NC, 28723. E-mail: yfan@email.wcu.edu
}

Project Management
Received September 16, 2015; received revision November 16, 2015; accepted on November 21, 2015

Available online January 16, 2016

\begin{abstract}
The following paper highlights the theories used to further project management (PM) research spanning the 15 year time period of 1999-2013. The analysis examined 273 articles drawn from seven widely recognized PM journals with the aim of uncovering the most utilized theories in the discipline's academic investigations. The review found these theories to be: Stakeholder Theory (ST), Fuzzy Sets Theory (FST), Utility Theory (UT), Theory of Constraints (TOC), and Actor-Network Theory (ANT). This collection of theories represents a diverse group of thought constituting a large portion of the PM literature's theoretical foundations. Both UT and TOC have diminished in popularity while ANT and ST have improved in favor; FST has remained consistent in its use. The appendix to this manuscript includes a "ready reference" of all the theories utilized in PM research found within the reviewed journal outlets from the 15 year review period.
\end{abstract}

Keywords: Theory review, actor-network, fuzzy sets, constraints, stakeholder, utility.

\section{Introduction}

Since the early 1950s, project management (PM) has been viewed as an academic "discipline" (Cleland and Gareis, 2006, p. 1). Over the years, PM has come into its own as a major sub-discipline within the management field, and has generated multiple avenues of academic knowledge, streams of practitioner methodology, and a library of best practices.

In an appendix to the Project Management Institute's (PMI) report on the future of PM (PMI, 1999), Fugate and Knapp (1999) posited that a body of theoretical knowledge is a key component of any established profession, and mastery of that theory, along with practical skill, separates profession from craft. The PM literature is replete with manuscripts utilizing theories from several of the reference disciplines, including psychology, engineering, and mathematics. PM academics have posited theories of PM (Shenhar and Dvir, 1996), as well as claimed there are no definitive theories of PM (Koskela and Howell, 2002). Taken as a whole, the broad collection of literature, grounded in a wide range of theory from multiple reference disciplines, represents the body of knowledge in the practice and art of PM.

PMI's 2014 Research and Education Conference was entitled Standing on the Shoulders of Giants: In Search of
Theory and Evidence. Concerned with the future of the discipline and the further development of PM knowledge, it highlighted how the discipline should build upon the research that has already been done in the field to further advance PM knowledge. Part of the conference's stated theme was to ascertain the role of theory within the discipline, and investigate if any progress has been made on further developing a theory of PM as called for in Koskela and Howell (2002). Clearly the PM discipline is beginning to pay more attention to the role of theory and theory development.

In light of this call for a greater understanding of the use of theory in the discipline, we offer the following paper as a guide to existing theory use within the PM discipline. In the following pages we address these research questions:

1. What are the top theories utilized in the PM literature over the period 1999-2013?

2. How were these top theories applied to PM research and practice?

3. What were the top theories usage trends, if any, during the period? 
26 Johnson, N., Creasy, T., and Fan, Y.

The remainder of this manuscript catalogues the primary theories cited in PM literature spanning the 15 years 1999-2013. Further, it offers the academic and practitioner alike a ready reference to the multitude of theories and theory development that has helped shape the academic body of knowledge within the PM discipline. Specifically, the manuscript uncovers the five most cited theories in PM literature, relates the theory's conception, and describes its application within PM literature and practice. The appendix also contains a detailed recounting of all papers and theories reviewed in the preparation of the manuscript, providing a quick reference for future research.

\section{Method}

To build this review, the appropriate academic journals had to be identified. We followed the lead of Littau et al. (2010), a previously published literature review, and used the identified PM outlets from that investigation. The following seven journals were used in this literature review: Project Management Journal, International Journal of Project Management, International Journal of Managing Projects in Business, Construction Management and Economics, Journal of Construction Engineering and Management, Automation in Construction, and International Journal of Project Organisation and Management. The search dates for the review were 1999 to 2013. Editorials, book reviews, and other non-peer reviewed items were discarded, scoping our review to peer-reviewed work only (Littau et al., 2010).

The target journals were then examined for the words "theory" or "theories" within the title, abstract, and/or key words to identify study-relevant articles. For papers containing more than one theory, the dominant (or base) theory was considered to be that manuscript's primary theory. Next, the relevant articles were categorized by theory and tabulated. After tabulation, the five top theories were investigated to ascertain the theory's primary use in its originating paper. Then, we captured how the theory has been positioned in the PM literature. Based on the theory's positioning in the PM literature, we developed conceptual "themes" for each theory (please refer to Fig. 1 for research process).

After analysis was conducted of all papers published in the reviewed journals, the top five theories in use were: Theory of Constraints, Actor Network Theory, Fuzzy Sets Theory, Utility Theory, and Stakeholder Theory. Please refer to Fig. 2 for a visual of their frequencies across the review time period. Each theory is detailed in the following section according to this format a) theory's origin; b) theory discussion; c) theory's general application; and d) theory's use in PM.

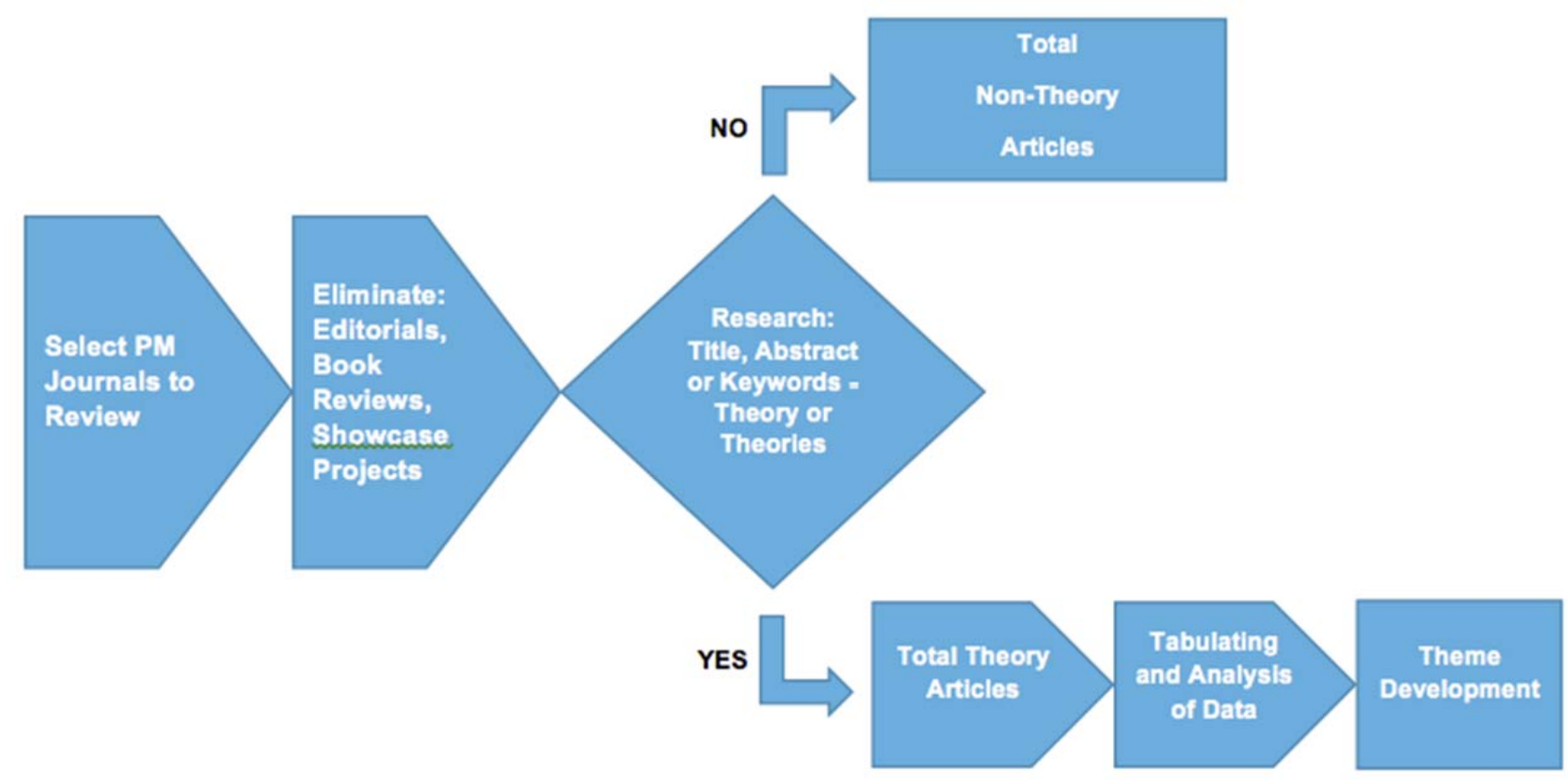

Fig. 1. Research process 


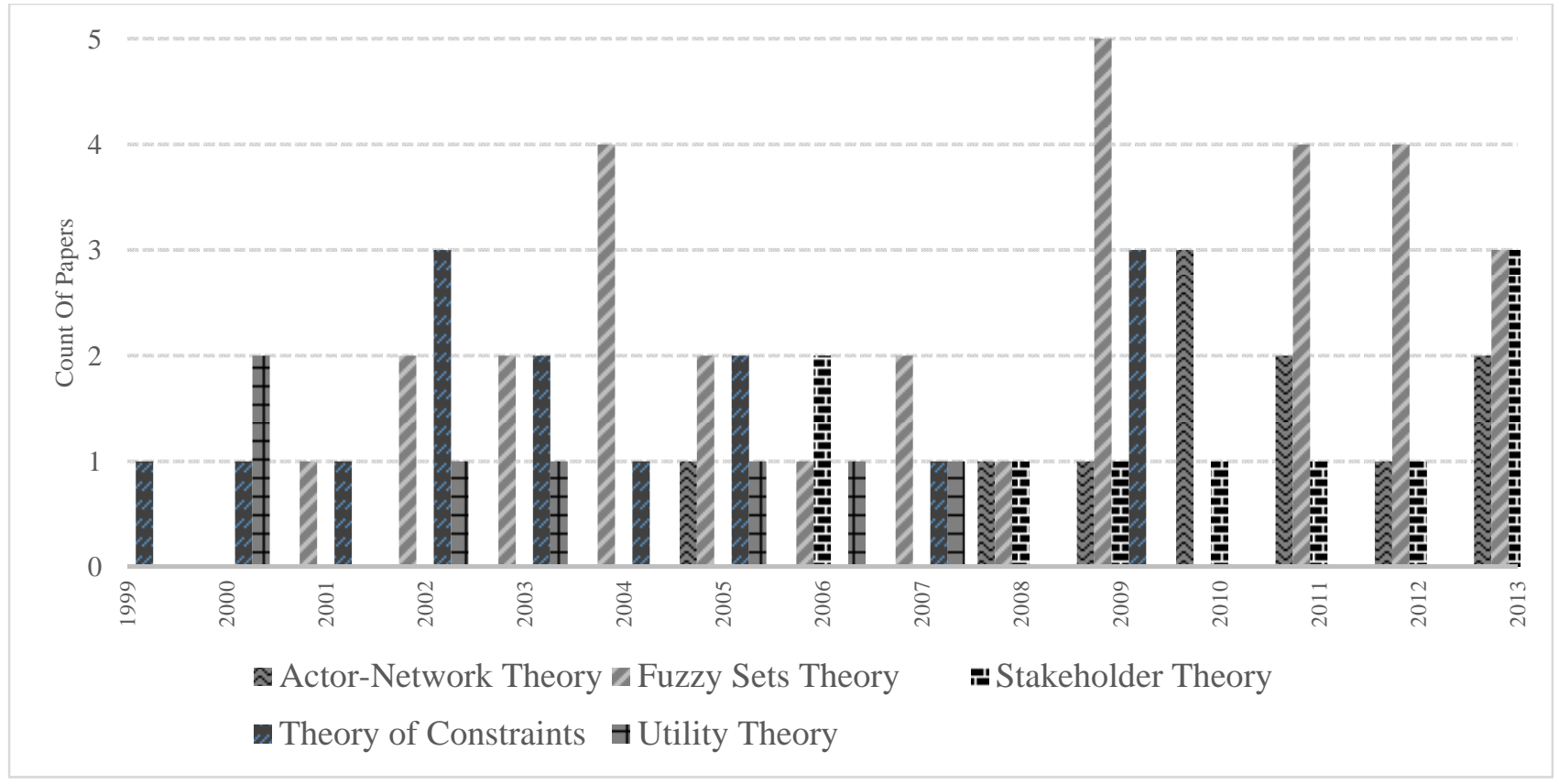

Fig. 2. Papers by theory and publication year

\section{Analysis of the top five cited theories from the reviewed PM literature, 1999-2013}

\subsection{Fuzzy Sets Theory}

Fuzzy Sets Theory (FST) found its genesis in a 1965 paper by Lofti Zadeh. The term "fuzziness" defines a symbol that characterizes a set of objects with ambiguous borders (Dubois and Prade, 1980). In Zadeh's original manuscript, he used the notion "classes of objects" and posited that most "...classes of objects in the real physical world do not have precisely defined criteria of membership" (1965, p. 338). He followed this with an example using a "class" of animal. We know that animals are cats, lions, sharks, etc.; dirt, furniture, and cars are clearly not in that class of objects... there is no question. However, the status of dogs, fish, and moose within the class "animal” is more nebulous. This same ambiguity can be applied to all manner of objects, including numbers. Since many objects don't fall into easily defined categories, FST has been hailed as an appropriate vehicle for modeling virtually any type of vague or ill-defined phenomena (Smithson, 1982). FST sharpens "fuzzy" inputs such as oral statements, by converting them to quantitative data through mathematics and formal logic (Klir and Yuan, 1995).

Although not found directly in the PM literature, FST began to appear in the literature of related disciplines in the late 1980s. Lehtimäki (1987) applied FST to supply chain management issues regarding supplier approval of customer change orders. Since change orders may require multiple decisions to be made regarding scheduling and delivery, factors that are often fluid and ill-defined, fuzzy logic could be applied to address them. Kangari and Halpin (1990) soon followed in their work utilizing FST to investigate the need-based, technological, and economic feasibility of automation in various construction projects. Recently, Kabir and Sumi (2013) combined FST and Delphi Method to develop a multicriteria inventory classification model.
FST started to come more into the sphere of PM in the mid-90s, with heavy emphasis continuing in the construction literature. Huat and Low Sui Pheng (1994) applied FST in their discussion of the Singapore construction industry and the industry maturity grid (IMG) tool. By applying FST to decision models in the IMG, the authors found its typical qualitative features can be converted to a semi-quantitative method for capturing expert judgments via a linguistic scale (e.g. comments such as "highly unlikely" are converted to a numerical scale). Continuing in a construction theme, Moselhi (1995) proposed a risk-pricing algorithm utilizing FST to help contractors decide on appropriate bid prices for highway construction projects. That same year, Wong and So (1995) posited a reasoning model utilizing FST to assist in contract type decision making processes.

Mak (1995) reviewed analytical risk analysis in the construction industry and opined that although information technology (IT) resources were making risk analysis more affordable and precise, they were not always the most accurate. FST was found to be applicable to risk analysis making it a viable alternative to IT enabled analysis. Risk analyses utilizing FST were found to provide more accurate and interpretable results than IT enabled analysis (Mak, 1995). Lorterapong and Moselhi (1996) further brought FST into the PM literature when they applied the theory to network scheduling and path creation.

More recently, and within the scope of our literature review, the PM discipline has found a range of uses for FST. For instance, FST has been used to analyze risk elements in the development of project financial models (Sachs and Tiong, 2009), construction projects (Baloi and Price, 2003; Nieto-Morote and Ruz-Vila, 2011; Okoroh and Torrance, 1999), and has aided in the creation of enterprise risk management schema (Zhao et al., 2013). The theory has also been utilized to develop a monitoring and controlling geographic information decision support system (DSS) for excavation activities (Cheng et al., 2002), as well as a DSS for observing hillside stabilization rates (Cheng and Ko, 2002). FST has also 
28 Johnson, N., Creasy, T., and Fan, Y.

been used in fault tree analysis (Nang-fei Pan, 2006) and found to be useful because estimating the probability of fault events related to human error was difficult. The FST model developed in the paper can be helpful for safety engineers to better assess the integrity of buildings.

FST has been found a useful method for tackling the vagueness of cost, time, and activity duration inputs (Ashuri and Tavakolan, 2012; Chou et al., 2013; Maravas and Pantouvakis, 2012; Shi and Blomquist, 2012; Wang and Liang, 2004). It has also been used to examine a range of trade-off problems (time and cost) (Eshtehardian et al., 2008; Sou-Sen Leu and An-Ting Chen, 2001; Zahraie and Tavakolan, 2009; Zheng and Ng, 2005). Ammar et al. (2013) and Kishk (2004) examined wholelife costing models and the utilization of FST in providing data and input where historical and other empirical data are imprecise.

FST has been used to analyze enterprise resource planning (ERP) selection projects in Taiwan (Wei and Wang, 2004). Utilizing FST, they were able to create aggregated weights for selection criteria by utilizing linguistic and subjective inputs concerning choices about ERP systems. Subsequently, Wei et al. (2007) examined supply chain selection criteria and utilized FST to aid in assessing linguistic evaluations of competing supply chain systems.

In Tzu-Liang Tseng et al. (2004), project team formation is the focus. Specifically, they address multifunctional teams working in distributed networks across different functional areas. These team formations are vital for project success, but are often plagued by poor communication and inadequate information (i.e. vague and fuzzy inputs) in the initial stages of team formation. FST is used to build a methodology for addressing these issues. Kale (2009) explored how construction companies are becoming increasingly cognizant of how they manage their knowledge assets in order to remain competitive. Combining an intellectual capital index with FST, Kale (2009) offered business executives the prospect of identifying their strengths, weaknesses, and business opportunities by developing a framework that dealt with the vagueness and uncertainties of intellectual capital.

Several research projects dealing with contractor/subcontractor selection have employed FST. Singh and Tiong (2005) applied FST when examining a contractor's capability in completing projects according to buyer specifications. Since buyers are increasingly looking at more than simple tender price when choosing a contractor, a selection method involving FST is developed to incorporate multiple capabilities of the possible contractor into the decision making process. Likewise, Juan et al. (2009) applied FST with positive results when investigating ambiguous projects concerning contractor refurbishment work involving risk, uncertainty, and coordination inputs. They found that while selecting the appropriate contractor is critical to project success, a pre-qualification process can be utilized to make sure any contractor considered for tender is adept and capable. Similarly, Plebankiewicz (2012) and Nieto-Morote and Ruz-Vila (2012) examined FST's use in contractor prequalification procedures. Yang et al. (2003) explored how FST can be combined with House of Quality to create a type of fuzzy Quality Function Deployment system for evaluating how well client expectations line up with design and construction processes. Employing FST, Xia et al. (2011) addressed design-build (DB) variations available to customers, and created a multi-criteria decision making model for choosing the best variation option. Using the provided model, potential customers would be able to quantitatively assess the assorted DB variations available to them. FST has been used in a myriad of ways in PM research. It is likely that the theory will continue to influence future PM research.

\subsection{Theory of Constraints}

In 1988, a "radically new" approach to controlling and managing the flow of materials (and later resources) in factories was developed by Eliyahu Goldratt published what has been referred to as the "Theory of Constraints" (TOC) (Goldratt, 1988). TOC has been considered a management philosophy that considers a limited number of assumptions designed to provide a process for continuous improvement. According to Watson et al. (2007), many notable organizations have utilized TOC successfully including 3M, Amazon, and Boeing to name a few.

Some have referred to this systemic approach as "Management by Constraints” (Ronen and Starr, 1990). While studying TOC's application, a constraint was summarized as “...anything that limits a system's performance...” (Lin et al., 2009). Most businesses or projects can be considered a system of ordered, process steps. As such, when considering improvement aims rather than keeping with the traditional improvement approaches - breaking down a process and improving the efficiency of each step - this theory “...requires managers to focus on bottlenecks, or constraints, that keep the process from increasing (or improving) its output" (Bevilacqua et al., 2009). In order to improve the output or efficiency of any system in accordance with Goldratt's TOC (Goldratt, 1984) five successive, improvement steps are required: 1) identify the system's constraint, 2) decide how to exploit (or “elevate”) the system's constraint, 3) subordinate all other processes to the constraint, 4) decide how to eliminate the system's constraint, and 5) reanalyze the system identifying the next constraint and do not allow inertia to become the next constraint.

Goldratt first introduced the possibilities of TOC within PM and specifically toward scheduling in the book Critical Chain when he defined the "critical chain" as the path that determines project duration (Goldratt, 1997). With the publication of this book, TOC transitioned from the factory floor to PM in 1997. When considering the application of PM and critical chain, Shu-Shun and Shih (2009) refer to TOC as "a conceptual theory that treats schedules as problems of resource insufficiency and risk issues” (p. 859). Later, TOC was employed across various PM manuscripts dealing with: improving control and resource allocation, project cost management, project risk management, and single project scheduling to reduce project duration (Steyn, 2002).

Critical chain seems to be in response to Parkinson's Law (Parkinson, 1957), which posits that "work expands to fill the time given for execution" (Cohen et al., 2004, p. 40). Rand (2000) suggests, "The reason for the development of Critical Chain is the existence of chronic problems that existing methods, approaches and even expensive software have not been able to remove” (p. 174). It was reasoned that critical chain thinking reduces predicted activity durations by eliminating safety margins. 
Further, Cohen, et al. (2004) stated, “critical chain methodology aims at developing a sound schedule, using buffer management, in order to avoid project overruns... it gives project managers a heuristic framework and guidelines for project managers on how to plan, schedule, and control their projects...” (p. 40).

Several researchers have praised the use of TOC (or critical chain) within the PM literature (Leach, 1999; Steyn, 2002 and 2000), while others have been more reserved (Shou and Yeo, 2000; Herroelen et al., 2002; Herroelen and Leus, 2001). Several of the similarities and differences between critical chain and traditional PM practices have been noted in the literature, particularly in those investigations of critical chain's applications within PM initiatives. "The critical chain is similar to critical path PM although there are three major differences: the method of assigning activity times, the use of buffers, and the elimination of resource conflicts" (Bevilacqua, et al., 2009, p 420). Within PERT/CPM, safety times are added at the end of each activity. Conversely, in critical chain thinking, safety times are aggregated and relocated toward strategic positions, otherwise viewed as "padding," and are used to protect the project's critical path of activities. The time estimates or durations of activities may be reduced but a project buffer is added at the end of the project. Some have been critical of the Theory of Constraints. Wei et al. (2002) noted an absence of a rule to establish the resource buffer, posited that the right time to employ the project buffer and "feeding buffer" is ambiguous, and determined that since the difficulty and duration of activities are not identical. As such, applying a standardized cut to all activities could be ill advised. Cohen et al. (2004) stated that, "The methodology is not well defined in the sense that it does not provide precise definitions for some project entities and scenarios" (p. 40).

Moreover, Goldratt himself has received substantial critique. Duncan (1999) posits that TOC borrows heavily from systems dynamics developed by Forrester in the 1950s and from World War II era statistical process control. More recently, Herroelen et al. (2002) suggested that "this concept (critical chain) is not new; Wiest (1964) introduced the concept of a critical sequence more than 30 years ago" (p. 50). Additionally, Trietsch (2005) declared that TOC should be thought of, not as a theory, but more "management by constraints". Alternatively, Steyn (2000) concluded his comments by saying, "The application of the TOC principles to reduce project duration was by no means common prior to the advent of Critical Chain. The TOC approach puts together concepts that have not been put together in the same way before and is therefore considered an innovation" (p. 369). Although opinions differ as to the roots of TOC, emphasis on the "critical chain" appears to be a viable activity for project managers.

\subsection{Actor-Network Theory}

Actor-Network Theory (ANT) originated in manuscripts by Michel Callon (1986) and Bruno Latour (1987). ANT has been defined as a "material-semiotic" method that accounts for the essence of nature and societies. It accomplished this by positing how various materialsemiotic mechanisms interrelate to act as a single entity (Latour, 2007).

One of the strengths of the actor-network concept was its ability to provide analytical tools for explaining how new technologies are adopted into practice. Scholars studying ANT asserted, "the strength [of the organization, culture, or society] does not come from concentration, purity and unity, but rather from dissemination, heterogeneity and the careful plaiting of weak ties" (Latour, 2007, p. 3). ANT investigators posited that "innovation can be described in a network vocabulary that emphasizes the interrelated and heterogeneous relations of all its components, whether social or technical" (Bijker and Law, 1992, p. 18). Additionally, ANT can be employed to understand how professionals within the network interact with physical technologies and artifacts to create outcomes (Lingard et al., 2012).

ANT's ontological framework is also useful for investigating socio-technical interactions. One of its key features is the notion of "symmetry" in which neither a social nor a technical position is privileged (Lingard et al., 2012). Instead, "both material and semiotic components should be integrated into the same conceptual framework to avoid technological or social determinism" (Latour, 2005, p. 84). According to Latour (2005), an actornetwork may not be a technical network - it may have no compulsory paths, no strategically positioned nodes, nor limit itself solely to human actors but extend the word actor - or "actant" - to non-human entities.

To examine the dynamic process of association, change and reconstitution between actors and actants in a network, scholars must identify various actors of the network and examine when and how they interact (Latour, 2005; Lingard et al., 2012). Actors can be classified into "intermediaries" and "mediators". An intermediary is defined as a passive entity of the network that "transports meaning or force without transformation (Latour, 2005, p. 39).” In contrast, mediators are active entities within an actor-network that "translate, distort and modify the meaning of elements they are supposed to carry" (Latour, 2005, p. 39) with more uncertainties.

Actor-networks are characterized by continual transformations and reconfigurations of actors and artifacts occurring through interaction (Harty and Whyte, 2010). In a network those actors will be associated in such a way that they "make other actors act through transforming their world” (Latour, 2005, p. 107).

In 1990, ANT became a popular tool for analyzing disciplines such as informatics, health studies, geography, organizational analysis, anthropology, sociology, feminist studies, and economics. Additionally, ANT began to be used as a method for developing PM knowledge (Pollack et al., 2013). Linde and Linderoth (2006, p. 156) posited that ANT “...can be applied to the analysis of a project process and can expand project management theory. This approach has some useful implications for practitioners.” ANT has also proven useful in shifting PM research more toward behavioral elements, and away from its bias regarding tools and techniques (Leybourne, 2007, p. 69).

Several extensive uses of ANT exist in the PM literature. Blackburn (2002) employed ANT in summarizing actions project managers perform in practice. Sage et al. (2011) posited that “...an ANT perspective on project complexity is worthy of more attention” (p. 288). Parkin (1996) and Harty and Whyte (2007) engaged ANT to study decision making in PM, while Aubry et al. (2007) used ANT to discuss relationships between various actors in PM offices. 
Although slow to start, ANT seems to have secured a place in the PM research community.

\subsection{Stakeholder Theory}

Stakeholders play a crucial role in successful project outcomes (Beringer et al., 2013; Aaltonen, 2011; Assudani and Kloppenborg, 2010; Wang and Huang, 2006). Research has shown a strong relationship between project performance and stakeholder management (Donaldson and Preston, 1995). Moreover, various researchers (Mitchell et al., 1997; Jamali, 2008; Walker et al., 2008) suggested that stakeholders (as a result of their influence and power) created and sustained values, goals and PM performance targets. Considering such, it seems prudent for project managers to engage in some level of stakeholder management.

"Stakeholder theory is a theory of organizational management and ethics” (Phillips et al., 2003, p. 480) whose concept originated from strategic management (Beringer et al., 2013). Stakeholder Theory (ST) had its roots in the year 1984 when Freeman defined stakeholders as "any group or individual who can affect or is affected by the achievement of the organization's objectives" (Freeman, 1984, p. 46). Freeman and Reed (1983) acknowledged the growing connectedness of external stakeholders (e.g. environment, communities, “commons") across ever increasing permeable organizational boundaries. ST with its triple effect of descriptive accuracy, instrumental power and normative validity (Donalson and Preston, 1995) has appeared in various forms which are crucial in understanding and describing the dimensions and structures of societal and business relationships (Carroll, 1993; Jamali, 2008). Further ST has been viewed in different perspectives - the social science ST, instrumental ST and convergent ST (Bourne and Walker, 2006). The basic assumption of ST is "...that a firm, represented by its management, has relationships with many constituent groups of individuals in the firm and in its external environment, and that those groups do not only play a vital role in the success of a firm, but also the interests of all (legitimate) stakeholders...” (Beringer et al., 2013, p. 18).

Prior to discussing the elements of stakeholder management, it may be necessary that we first consider the components of a "stakeholder's stake." According to Carroll and Buchholtz (2000, p. 65), a stake could be a right, ownership or an interest. A right is either a "legal right when a person or group has a legal claim to be treated in a certain way or to have a particular right protected" or a "moral right." Ownership is a circumstance "when a person or group has a legal title to an asset or property." An interest is defined as a circumstance in which "a person or group will be affected by a decision; it has an interest in that decision" (Carroll and Buchholtz, 2000, p. 65). The majority of projects will have one, two or all three types of stakeholders. "Most project stakeholders will have an interest, many will have a right....and some will have ownership” (Bourne and Walker, 2006, p. 6).

The "stakeholder" was defined by Sutterfield et al. (2006) when they posited, "The generally accepted definition of a stakeholder is an individual or group of individuals that are directly or indirectly impacted by an entity or task" (p. 27). According to Mitchel et al. (1997), three attributes of a stakeholder were proposed: 1) legitimate relationship with the organization, 2) power to influence the organization, and 3) urgent claim on the organization. He posited that at least one of those attributes must be present for the existence of stakeholder status. Kaler (2009) categorized stakeholders into two groups: "primary stakeholders" and "secondary stakeholders;" the former being employees and shareholders, and the latter being customers, lenders and suppliers. Sutterfield et al. (2006) furthered stakeholder research by asserting that a project stakeholder is "any individual or group of individuals that is directly or indirectly impacted by a project. Stakeholders can be internal or external to the project team or they can be internal or external to the project scope” (p. 27).

The field of PM was introduced to stakeholders, and the processes included in stakeholder management, by Cleland (1986). This introduction was made possible through the emphasis of stakeholder identification, classification, analysis and approaches to management. One of the key soft skills that successful project managers must possess is stakeholder management (Morris et al., 2006; Winter et al., 2006; Crawford, 2005). The process of stakeholder management is comprised of the following steps: 1) stakeholder identification, 2) stakeholder classifications (including "internal” or "external” and high/low influence levels), 3) stakeholder analysis (including stakeholder project views of "for," "against” or "neutral”), and 4) frequent stakeholder communications modes ("lean" or "rich") as prescribed in the communications plan.

Project managers can better ascertain the stakeholder's goals, objectives, and level of project understanding by collecting stakeholder requirements and expectations. Active stakeholder management provides several potential benefits to project outcomes, including a decrease in the likelihood of the project failure due to unresolved issues and a limiting of distractions to the project (PMI, 2013). The importance of the "art" of stakeholder management seems likely to increase as organizations' projects grow in complexity which includes rising levels of informational "noise," conflicting priorities, political pressures, seemingly incongruent tasks and competition for resources.

\subsection{Utility Theory}

Economists have used the term utility to characterize personal happiness. In the literature, Utility Theory (UT) has been defined as a means to understand individual choices and preferences when maximizing a utility function (Brickley et al., 2001).

First proposed by Daniel Bernoulli in 1738 (Chen and Lee, 2000), Expected Utility Theory (EUT), a category of UT, plays an important role in management science and decision-making under conditions of uncertainty (Einhorn and Hogarth, 1986; Kutsch and Hall, 2005). Specifically, the EUT is for decision makers to determine individual's preferences between complex alternatives with uncertain and/or multi-dimension outcomes. This theory has been generally accepted in risk management literature as a model of rational choice for making risky decisions (Jaeger et al., 2001).

Unlike expected value criterion, which only takes into account the sizes of payouts and the probabilities of occurrence, implying that both the payoffs and the 
probability are linear function (Chen and Lee, 2000), the EUT model suggests that rational individuals also take into account stakeholder's risk attitude in maximizing expected utility. The risk attitude is directly related to the curvature of the utility function: risk neutral individuals have linear utility functions, risk seeking individuals have convex utility functions, and risk-aversion individuals have concave utility functions. The degree of risk aversion can be measured by the curvature of the utility function.

The management discipline is replete with studies of UT. For example, Greenberg and Collins (1966) and Krugman (1966) reported the use of UT in marketing research in brand-preference and related research. Simiarly, Read (1964) applied the theory to quality control applications in the food industry. UT has been employed to develop corporate strategies, assign electronic components to ships, evaluate product defects, and evaluate power-system alternatives (Fishburn, 1968).

Although UT has been considered one of the most successful works in management science (Chen and Lee, 2000), many psychologists criticized it, such as Kahneman and Tversky (1973, 1982), and Hogarth (1987). Most criticisms centered on the fact that judgments were made by decision makers that did not consistently follow the axioms of rationality (Chen and Lee, 2000; March, 1978). Additional criticism focused on inappropriate measurements of utility or probability (Ellsberg, 1961).

Risks and uncertainties are integral to projects, and as such, risk management is included as one of the knowledge areas in the PM Book of Knowledge (PMI, 2013) wherein several processes and tools for managing risk are defined. Stakeholder risk tolerance, and preferences in making decisions under the conditions of uncertainty, can be improved by the application of the rational approaches found in UT.

Piney (2003) presented a set of measures of expected utility values (EUV), rather than using expected monetary values (EMV), to accommodate stakeholders view of risk toward project risk propensities. This expected utility measurement presents a variable named "regret" for negative impact, and extends this concept to include positive ("rejoice") outcomes as well as after-the-event reviews, for which a "resentment" value is described. By doing so, the project managers are able to understand the nonlinear and asymmetric nature of the utility curve, factor in the utility value of the impacts of uncertainties, and take into account project stakeholders' specific tolerance to risk. In order to make the decision-making processes more objective, and to accommodate different decision makers' preferences, Elmisalami et al. (2006) applied UT to construction projects by integrating technical, economic and risk attributes into a multicriterion model.

A conceptual approach for applying UT to contractor selection was developed by Nicholas et al. (2000). The buyer organization's risk attitude (risk averse, risk neutral, and risk seeking) was measured in balancing the potential gains with the risks and efforts on achieving utility increase. With a knowledge of potential gains and losses, discretion based on the notion of "gut feelings" was reduced and replaced to some extent with decisions based on qualitative and quantitative knowledge. Similarly, when dealing with contractor selection, Wang (2002) presented a UT based model that simulated a cost approach to reflect owner's preferences.

Despite the fact that EUT has proven a rational approach to understanding project risk, concerns remain with activities that interrupt risk management processes predicted by UT. Kutsch and Hall (2005) demonstrated that project managers often ignore, avoid, deny, or even delay dealing with risk due to decision maker and environmental conditions. As a result, risk management processes are adversely impacted. The authors argue that those intervening conditions in project risk management deviate from the claims of this theorem, and many psychological factors are not adequately captured by EUT.

\section{Discussion}

Our review has revealed that theory has had its place in the PM community. During this manuscript's period of study from 1999-2013, there were 131 various theories applied or expounded upon within the reviewed PM literature. In consideration of Fig. 3, which exhibits the total number of theories used per year in the review period, it appears that theoretical inclusion within the PM literature has trended up over the study period. This trend suggests that theory has played a significant role in PM thought and practice, and those trends are likely to continue into the near future. Although Koskela and Howell (2002) called for further theory development and use, it appears that, based on the parameters of this study, theory use was already trending up at that time (Fig. 3). Additionally, after their call for increased theory presence, and perhaps due in part, theory utilization in the PM literature continued to trend positively (Fig. 3).

Examining in more detail the occurrence of theory in PM literature, it is possible to study the slope of two trend lines to ascertain what, if any, difference occurred. The trend line up to Koskela and Howell's (2002) call for more theory (1999-2002), and the trend line post that call through the duration of the study period (2003 - 2013) offer insights. By examining the slope of each trend line, it appears that theory inclusion in PM literature accelerated slightly after Koskela and Howell's (2002) work. Fig. 4 offers both trend lines and respective slope equations. It appears that the time from 2003 to 2013 enjoyed a slope of 1.99 while that of 1999-2002 saw a slope of 1.30 . This represents a $53 \%$ increase in theory use count.

Narrowing the field to the top five theories, as presented in Table 1, are a diverse group. Table 2 shows the theories' origins and offers potential PM knowledge area application.

Mathematics forms the foundations of FST and allows qualitative data to be used for creating semi-quantitative information via a linguistic scale. Goldratt's (1997) TOC emphasized that all systems have a limiting factor, or "bottleneck." As such, practitioners must endeavor to identify the bottleneck, then minimize (or eliminate) said factor. In a departure from the quantitative arena, ANT centers its focus on networks. ANT scholars put emphasis on the technical components and social interrelations within the network. Distancing itself even further from the quantitative, ST was introduced to PM by Cleland 
32 Johnson, N., Creasy, T., and Fan, Y.

(1986). He advised that fostering relationships with stakeholders, via interpersonal affiliation, is key because it can positively or negatively influence project outcomes. Uncertain conditions surrounding managerial decisions created a need for UT. A strength of UT is its ability to ascertain an individual's preferences between complicated choices associated with potentially vague outcomes.

Related to UT, ST offers project managers rational decision-making support when considering stakeholder preferences and tolerances in uncertain environments. Considering that research has shown a direct relationship between project performance and stakeholder management, project managers are wise to engage in aggressive stakeholder management.

FST appears to be far and away the most active theory base for the PM literature in the 15 years under review. The PM literature has been heavily laced with manuscripts based on FST suggesting a flexible and wide-reaching theory useful for future research in many areas of PM. While UT and the TOC were both popular in the early part of the 15 year review, they have cooled in their relative employment by academics. On the other hand, ANT and ST were slow starters in the period of years reviewed for this paper. They have now overtaken UT and the TOC in their usage in the literature. Interestingly, the citations for each of these four theories have flip-flopped, while FST has remained fairly constant over the review period. A graphical analysis of the literature citation counts can be seen in Fig. 5. The slopes for each of the theory counts over the review time period have been plotted and overlaid on the graphs. Based on the historical use and precedence of these theories in PM literature, it may provide an indication of future utilization of these theories. If true, ANT and ST may continue to increase in their frequency of use in future PM literature whilst FST employment may remain constant.

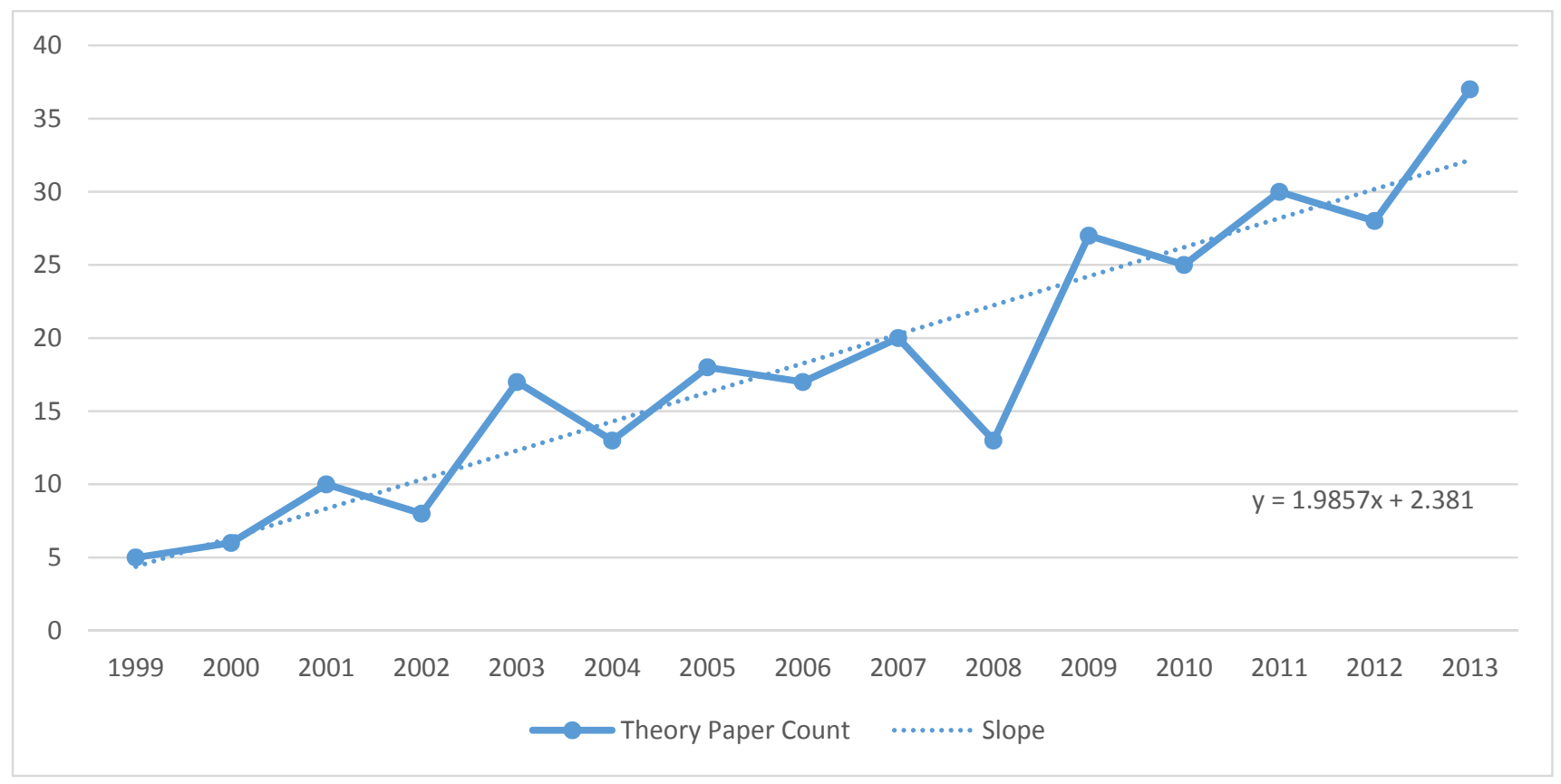

Fig. 3. Theory count per year 1999-2013 within reviewed PM literature 
12

10

8

6

4

2

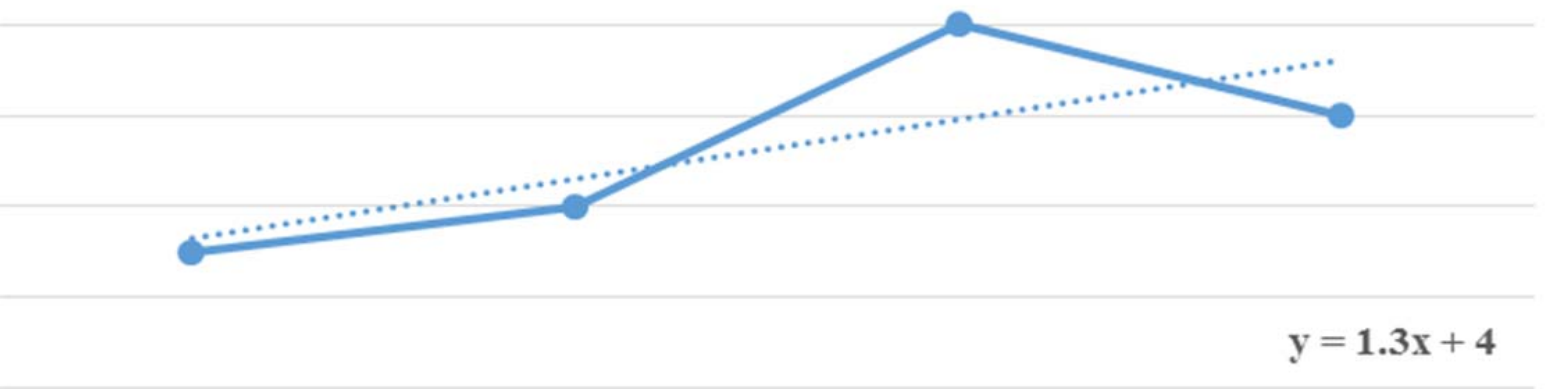

0

1999

2000

2001

2002

- Theory Paper Count

Slope

(a) Theory use paper count (1999-2002)

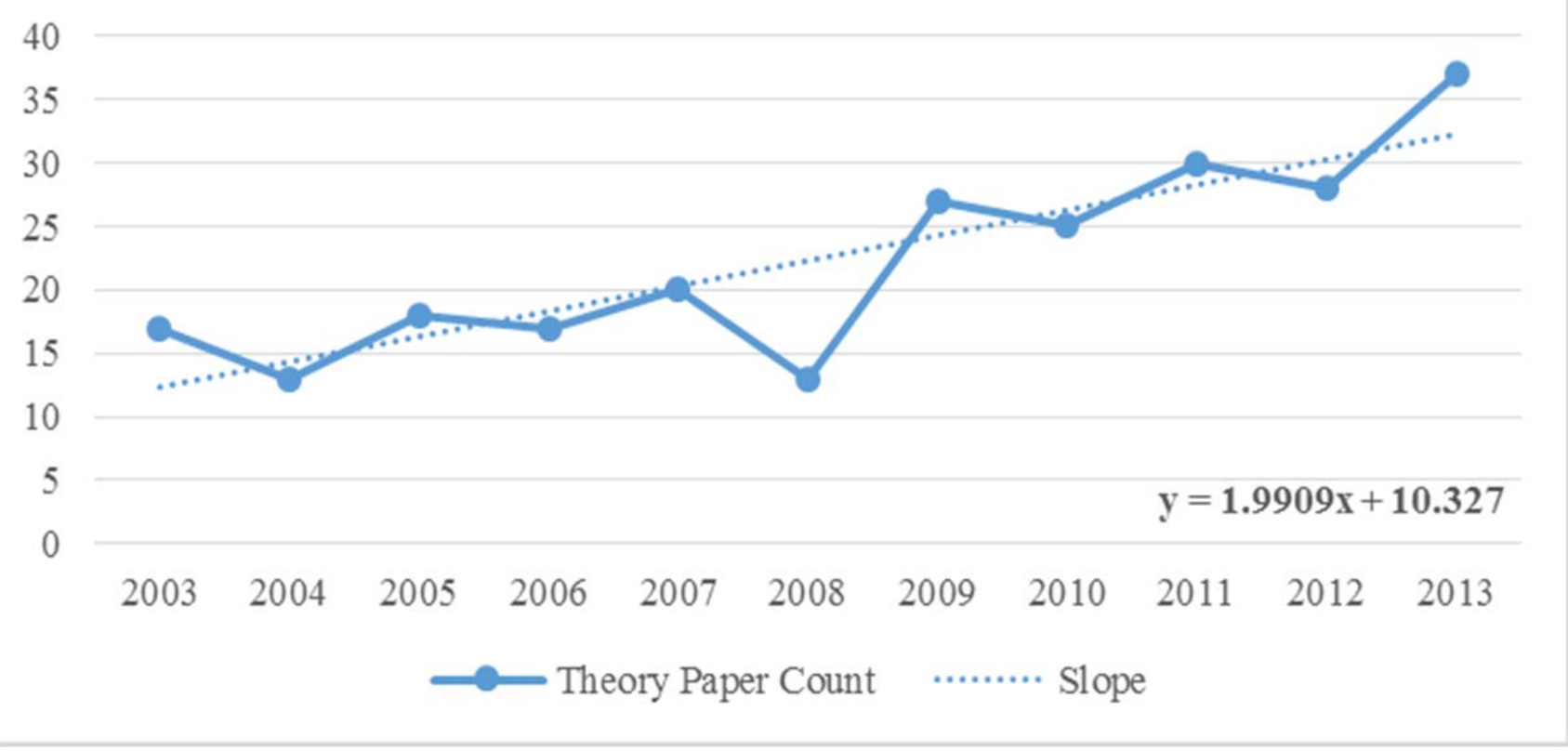

(b) Theory use paper count (2002-2013)

Fig. 4. Graphical analysis of citation counts in pm literature pre/post (Koskela and Howell, 2002) 
Table 1. Theory frequency by journal

\begin{tabular}{|c|c|}
\hline Journal Title and Theory & \# Articles \\
\hline Automation in Construction & 10 \\
\hline Fuzzy Sets Theory & 8 \\
\hline Theory of Constraints & 1 \\
\hline Utility Theory & 1 \\
\hline Construction Management and Economics & 15 \\
\hline Actor-Network Theory & 5 \\
\hline Fuzzy Sets Theory & 5 \\
\hline Stakeholder Theory & 2 \\
\hline Theory of Constraints & 1 \\
\hline Utility Theory & 2 \\
\hline International Journal of Managing Projects in Business & 4 \\
\hline Actor-Network Theory & 2 \\
\hline Stakeholder Theory & 2 \\
\hline International Journal of Project Management & 20 \\
\hline Actor-Network Theory & 2 \\
\hline Fuzzy Sets Theory & 8 \\
\hline Stakeholder Theory & 2 \\
\hline Theory of Constraints & 7 \\
\hline Utility Theory & 1 \\
\hline Journal of Construction Engineering and Management & 17 \\
\hline Actor-Network Theory & 1 \\
\hline Fuzzy Sets Theory & 11 \\
\hline Theory of Constraints & 3 \\
\hline Utility Theory & 2 \\
\hline Project Management Journal & 9 \\
\hline Actor-Network Theory & 1 \\
\hline Stakeholder Theory & 4 \\
\hline Theory of Constraints & 3 \\
\hline Utility Theory & 1 \\
\hline * None of the top five theories were found in the IJPOM & \\
\hline
\end{tabular}


Table 2. Theories' diverse origins and application areas

\begin{tabular}{ccc}
\hline Theory & Origin & PM Knowledge Area \\
\hline Fuzzy Sets & Logic and Mathematics & Scheduling, Costing \\
Stakeholder Theory & Strategy & Stakeholder Management \\
Theory of Constraints & Operations Management & Scheduling, Portfolio Management \\
Actor Network Theory & Psychology & Change Management \\
Utility Theory & Economics & Risk Management \\
\hline
\end{tabular}

6

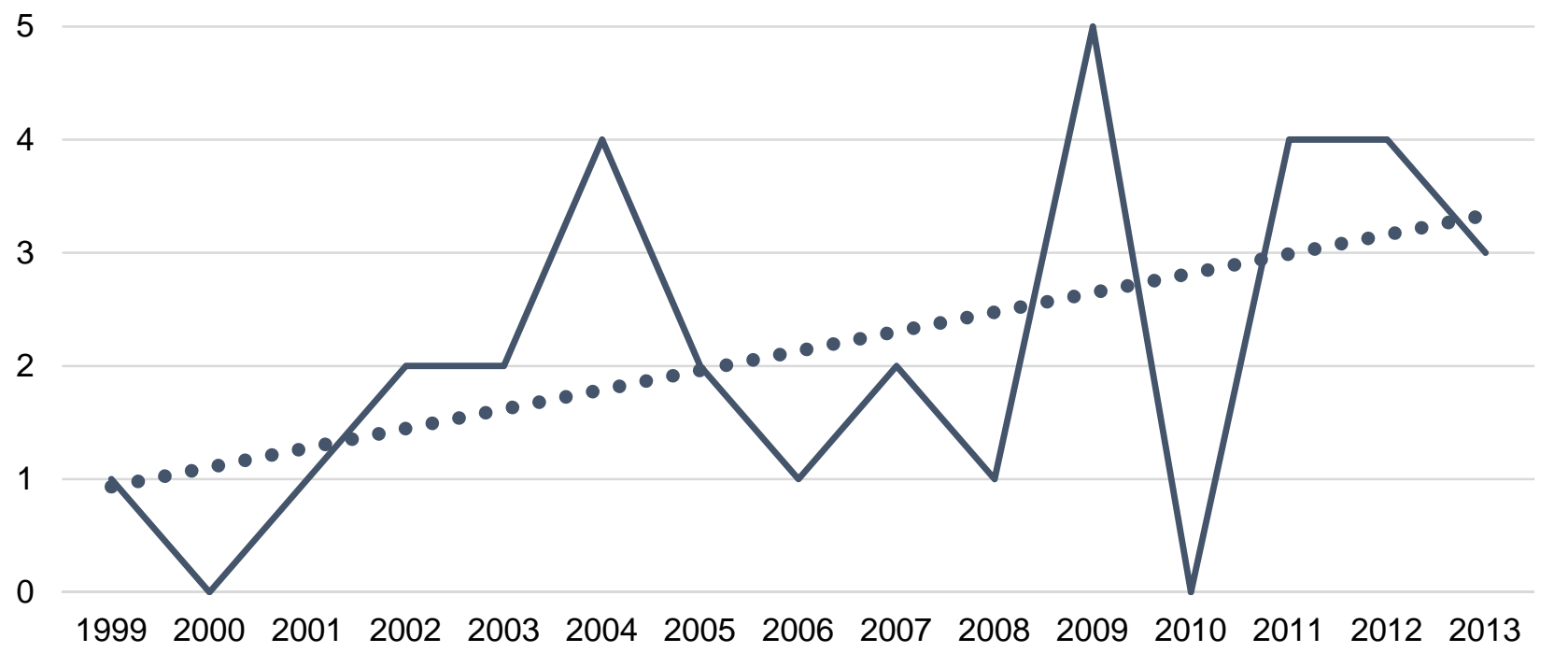

(a) Fuzzy Sets Theory

Fig 5. Graphical analysis of citation counts in PM literature 1999-2013 with trend 
4

3

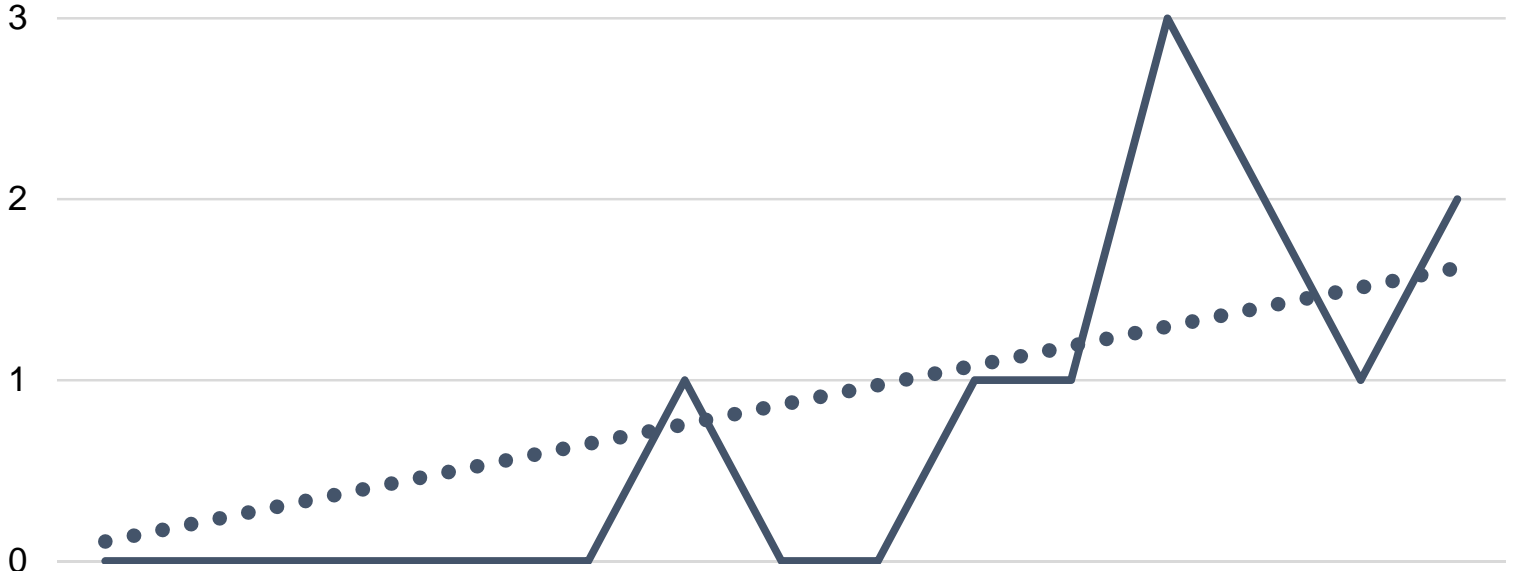

199920002001200220032004200520062007200820092010201120122013

(b) Actor-Network Theory

4

3

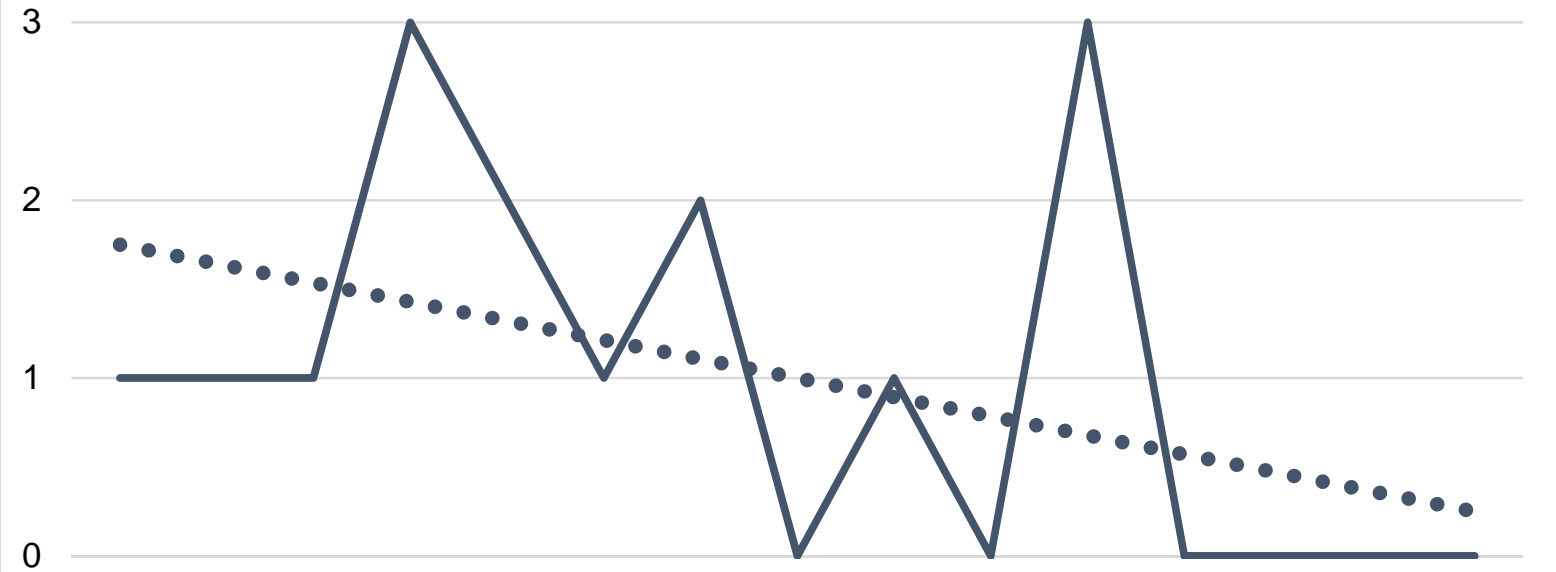

199920002001200220032004200520062007200820092010201120122013

(c) Theory of Constraints

Fig 5. Graphical analysis of citation counts in PM literature 1999-2013 with trend (continued) 
4

3

0

199920002001200220032004200520062007200820092010201120122013

(d) Stakeholder Theory

3

2

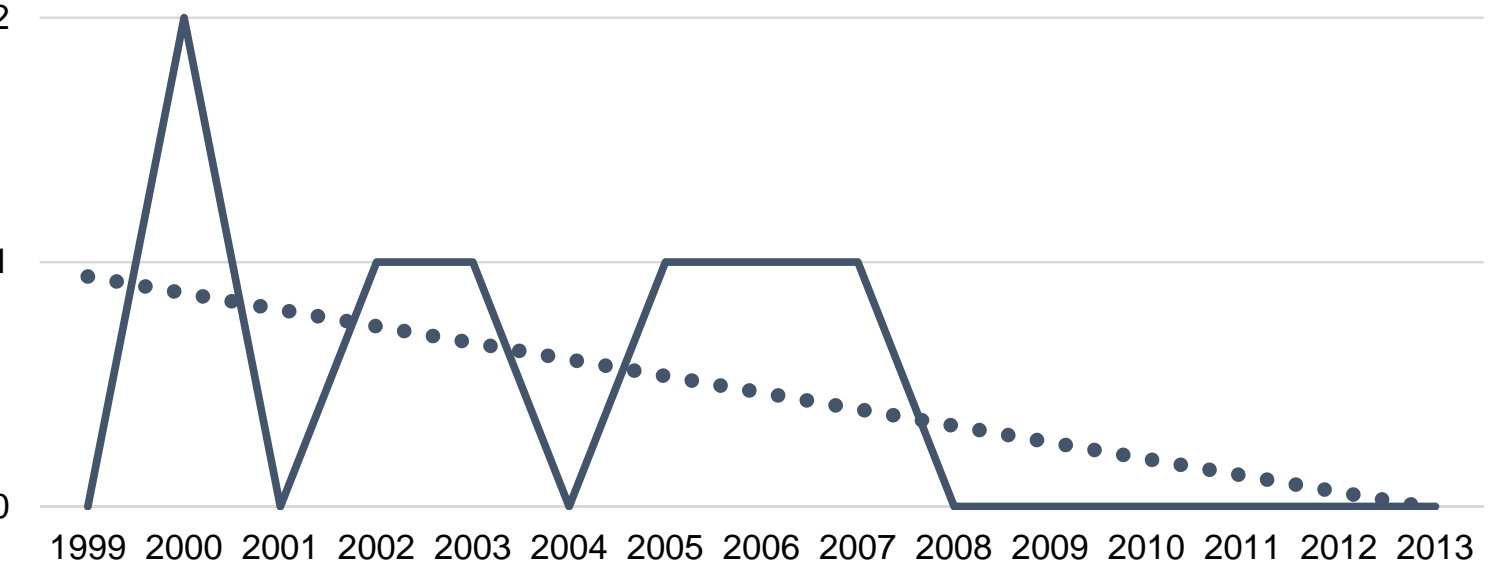

(e) Utility Theory

Fig 5. Graphical analysis of citation counts in PM literature 1999-2013 with trend (continued)

\section{Limitations}

Since our methodology followed the lead of Littau et al. (2010) for choosing the pool of peer reviewed journals to consider in our review, it does present a limitation in that we did not consider all PM journals, books, or other academic PM outlets. Subsequently, utilizing the Littau et al. (2010) method, we limited our search to the word theory in the reviewed articles' title, abstract or keywords. As such, there could be additional words or phrases revealing theory not collected here. Additionally, other theories may have been employed without the term theory appearing in our search criteria. Hence, the conclusions drawn in our review were formed from articles explicitly stating theory in our search criteria.
We recognize a recent 15 -year review does not cover the entire library of PM theoretical knowledge. However, our scope was designed to uncover recent theoretical trends in the PM literature.

\section{Contribution and future research}

As the PM body of knowledge continues to grow and expand, a meta-analysis considering the most utilized and/or cited theories within that knowledge domain seems reasonable. An additional aim of this research was to also bring attention to the strength and variety of the theoretical underpinnings of various PM researchers within the 15-year time period of 1999-2013. A significant contribution of this manuscript is the inclusion of all the theories found during our review (included in 
Appendix 1). This appendix should provide future investigators an advantage and "ready-reference" when considering theoretical implications within the PM knowledge domain.

FST has been utilized in time-cost trade off modeling, activity duration calculations, costing models, project selection, and risk management. Future research might investigate whether FST could be used as part of project manager selection or development programs.

TOC has been used within PM for project scheduling, improving project control, allocating resources, risk and cost management. TOC might be utilized in multi-project portfolio management and international, supply chain dependent projects. These seem like fertile ground for future TOC research.

ANT has been employed as a research methodology to discover new PM knowledge and has the ability to shift some PM investigations away from tools and techniques to behaviors. ANT has also been used in examining project complexity, PM decision-making and PM office interpersonal relations. ANT might prove a useful lens for research and evaluation of PM maturity in organizations or the strength of matrix-styled organizations as compared to other organizational forms when considering PM outcomes.

As it pertains to stakeholders, ST suggests the importance of identifying, classifying, analyzing and communicating with influencers who may cast a positive or negative effect on the project and/or its outcome. Considering the implications of not doing so could motivate project managers to become "stakeholder centric," thus increasing risk to other parts of the project. Considering such, future research might investigate what stakeholder management level is "ideal" for successful project outcomes so as to balance stakeholder needs with other project needs.

Finally, UT concerns itself with preferences and choices by utilizing a utility function. UT has found application with PM specifically in building relationships between contractors and suppliers. Future research could explore whether aspects of UT could be applied to project selection and/or team member selection. Further, UT might be utilized to resolve conflict in matrix-based organizations when conflict arises because of competing resource needs.

\section{Conclusion}

Our 15-year review indicates there to be a broad and diverse interest in theoretical application in PM research and practice. Moreover, the substantive dissimilarity in the composition of the theories within this review suggests an academic community that welcomes additional theoretical considerations.

Taking a closer look at specific theory usage in the study period, but narrowing the focus to the last four years (2010-2013), some of the top five theories continued to remain prominent while others rose in popularity. As the trends lines indicate in Fig. 5, FST, ANT and ST enjoyed positive trending, while TOC and UT's use among PM researchers trended down. In the last four years (2010-2013), FST, ANT and ST maintained their positive trend. However, two other theories, Contingency Theory and Grounded Theory, improved in researcher interest (Appendix 1). Narrowing the scope further to 2013 only, the three theories most probed among PM researchers were: FST, ST and Grounded Theory (Appendix 1). Based on the review's parameters, these theories seem to be peaking academic's curiosity in recent years and are pushing the discipline ever forward into new practice and philosophy.

Although a validated Theory of Project Management has yet to be developed or defined (Sauer and Reich, 2007; Turner, 2006; Williams, 2004), much theoretical inclusion has been conducted over the past several years. Indeed, the discipline has stood on the shoulder of giants and is continuing to evolve from a solely practice-based discipline to a more dynamic arena that finds significance in both practice and theory. Our work suggests that we are moving in that direction due to the varied theoretical implications found in this review. To that end, further inclusion of theoretical work should only strengthen the PM body of knowledge moving forward.

For any growing and sustainable academic body of knowledge, theory application and development must be present. This manuscript's review highlights the significant impact of several theories on the PM discipline. It is likely that each of these theories, among others, will continue to be further developed and find new application and purpose as the discipline evolves.

\section{References}

Aaltonen, K. (2011). Project stakeholder analysis as an environmental interpretation process. International Journal of Project Management, 29(2), 165-183.

Ammar, M., Zayed, T., and Moselhi, O. (2013). Fuzzybased life-cycle cost model for decision making under subjectivity. Journal of Construction Engineering \& Management, 139(5), 556-563.

Ashuri, B. and Tavakolan, M. (2012). Fuzzy enabled hybrid genetic algorithm-particle swarm optimization approach to solve TCRO problems in construction project planning. Journal of Construction Engineering \& Management, 138(9), 1065-1074.

Assudani, R. and Kloppenborg, T. (2010). Managing stakeholders for project management success: an emergent model of stakeholders. Journal of General Management, 35(3), 67-80.

Aubry, M., Hobbs, B., and Thuillier, D.(2007). A new framework for understanding organizational project management through the PMO. International Journal of Project Management, 25, 328-336.

Baloi, D. and Price, A. D. F. (2003). Modelling global risk factors affecting construction cost performance. International Journal of Project Management, 21(4), 261.

Beringer, C., Jonas, D., and Kock, A. (2013). Behavior of internal stakeholders in project portfolio management and its impact on success. International Journal of Project Management. 31, 830-846.

Bernoulli, D. (1954). Exposition of a new theory on the measurement of risk. Reprinted in Econometrica, XXII, 23-36.

Bevilacqua, M., Ciarapica, F., and Giacchetta, G. (2009). Critical chain and risk analysis applied to high risk industry maintenance: A case study. International Journal of Project Management, 27(4), 419-432. 
Bijker,W. and Law, J. (1992). Do technologies have trajectories? In Bijker, W. and Law, J. (Eds.), Shaping technology/building society: Studies in sociotechnical change (17-20). Cambridge, MA: MIT Press.

Blackburn, S. (2002). The project manager and the project-network. International Journal of Project Management, 20, 199-204.

Bourne, L. and Walker, D. (2006). Visualizing stakeholder influence-two Australian examples. Project Management Journal, 37(1), 5-21.

Brickley, J. A., Smith, C. W., and Zimmerman, J. L. (2001). Managerial Economics and Organizational Architecture. 2nd. McGraw-Hill Irwin.

Callon, M. (1986). Some Elements of a Sociology of Translation: Domestication of the Scallops and the Fishermen of St Brieuc Bay. In John Law (ed.), Power, Action and Belief: A New Sociology of Knowledge (London: Routledge \& Kegan Paul).

Carroll, A. (1993). Business and Society: Ethics and Stakeholder Management, 2nd edn, Cincinnati, $\mathrm{OH}$ : South-Western College Publishing.

Carroll, A. and Buchholtz, A. (2000). Business and Society: Ethics and Stakeholder Management. Cincinnati, OH: South-Western College Publishing.

Chen, C. and Lee, Y. (2000). Review and rethink the utility theory, Chinese Management Review, 3(3), 1-7.

Cheng, M. Y. and Ko, C.-H. (2002). Computer-aided decision support system for hillside safety monitoring. Automation in Construction, 11(4), 453.

Cheng, M. Y., Ko, C. H., and Chang, C. H. (2002). Computer-aided DSS for safety monitoring of geotechnical construction. Automation in Construction, 11(4), 375.

Chou, J. S., Pham, A. D., and Wang, H. (2013). Bidding strategy to support decision-making by integrating fuzzy AHP and regression-based simulation. Automation in Construction, 35, 517-527.

Cleland, D. I. (1986). Project stakeholder management. Project Management Journal, 17(4), 36-44.

Cleland, D. and Gareis, R. (2006). Global Project Management Handbook: Planning, Organizing and Controlling International Projects, Second Edition: Planning, Organizing, and Controlling International Projects (2 edition.). New York: McGraw-Hill Professional.

Cohen, I., Mandelbaum, A., and Shtub, A. (2004). Multiproject scheduling and control: a process-based comparative study of critical chain methodology and some alternatives. Project Management Journal, 35(2), 39-50.

Crawford, L. (2005). Senior management perceptions of project management competence. International Journal of Project Management, 23(1), 7-16.

Donaldson, T. and Preston, L. (1995). The stakeholder theory of the corporation: concepts, evidence, and implications. Academy of Management Review, 20(1), 65-91.

Dubois, D. and Prade, H. (1980). Fuzzy Sets and Systems: Theory and Applications. New York, NY: Academic Press.

Duncan, W. (1999). Back to basics: charters, chains and challenges. PM network, 13, 29-32.
Einhorn, H. J. and Hogarth, R. M. (1986). Decision making under ambiguity. Journal of Business, 59(4), 225-50.

Ellsberg, D. (1961). Risk, ambiguity, and the savage axioms. Quarterly Journal of Economics, 75, 643-669.

Elmisalami, T. Walters, R., and Jaselskis, E. J. (2006). Construction IT decision making using multiattribute utility theory for use in a laboratory information management system. Journal of Construction Engineering and Management, 132(12), 1275-1283.

Eshtehardian, E., Afshar, A., and Abbasnia, R. (2008). Time-cost optimization: using GA and fuzzy sets theory for uncertainties in cost. Construction Management \& Economics, 26(7), 679-691.

Fishburn, P. C. (1968). Utility theory. Management Science, 14 (5), 335-378.

Freeman, R. (1984). Strategic Management: A Stakeholder Approach. Pitman, Boston.

Freeman, R. and Reed, L. (1983). Stockholders and stakeholders: a new perspective on corporate governance. California Management Review, 15(3), 88-106.

Fugate, M. and Knapp, J. (1999). Appendix B: The Development of bodies of knowledge in the professions. In The Future of Project Management. Newtown Square, Pa: Project Management Institute.

Goldratt, E. (1984). The Goal. Great Barrington, MA: The North River Press, 2nd ed. (1986), 2nd revised ed. (1992).

Goldratt, E. (1988). Computerized shop floor scheduling. International Journal of Production Research, 26(3), 443-455.

Goldratt, E. (1997). Critical Chain. Great Barrington, MA: North River Press.

Greenberg, A. and Collins, S. (1966). Paired Comparison Taste Tests: Some Food for Thought. Journal of Marketing Research, 3, 76-80.

Harty, C. and Whyte, J. (2010). Emerging hybrid practices in construction design work: Role of mixed media. Journal of Construction Engineering and Management. 136, 469-476.

Herroelen, W. and Leus, R. (2001). On the merits and pitfalls of critical chain scheduling. Journal of Operations Management, 19, 559-577.

Herroelen, W., Leus, R., and Demeulemeester, E. (2002). Critical chain project scheduling: Do not oversimplify. Project Management Journal, 33(4), 48-60.

Hogarth, R. H. (1987). Human Judgment-An Overview. Judgment and Choice, 2nd Edition, John Wiley and Sons.

Huat, T. P. and Low, S. P. (1994). The fuzzy industry maturity grid (FIMG) and its application to the Singapore construction industry. Construction Management \& Economics, 12(2), 125.

Jaeger, C. C, Renn, O., Rosa, E. A., and Wehler, T. (2001). Risk, Certainty, and Rational Action. London: Earthscan.

Jamali, D. (2008). A stakeholder approach to corporate social responsibility: a fresh perspective into theory and practice. Journal of Business Ethics, 82(2), 21331.

Juan, Y.-K., Perng, Y.-H., Castro-Lacouture, D., and Lu, K. S. (2009). Housing refurbishment contractors 
40 Johnson, N., Creasy, T., and Fan, Y.

selection based on a hybrid fuzzy-QFD approach. Automation in Construction, 18(2), 139-144.

Kabiri, G. and Sumir, R. S. (2013). Integrating fuzzy delphi with fuzzy analytic hierarchy process for multiple criteria inventory classification. Journal of Engineering, Project, and Production Management, 2013, 3(1), 22-34.

Kahneman, D. and Tversky, A. (1982). Variants of Uncertainty. Cognition, 11, 143-157.

Kahneman, D. and Tversky, A. (1973). On the Psychological of Prediction. Psychological Review, 80, 237-251.

Kale, S. (2009). Fuzzy intellectual capital index for construction firms. Journal of Construction Engineering \& Management, 135(6), 508-517.

Kaler, J. (2009). An optimally viable version of stakeholder theory. Journal of Business Ethics, 86(3), 297-312.

Kangari, R. and Halpin, D. W. (1990). Identification of factors influencing implementation of construction robotics. Construction Management \& Economics, 8(1), 89.

Kishk, M. (2004). Combining various facets of uncertainty in whole-life cost modelling. Construction Management \& Economics, 22(4), 429-435.

Klir, G. J. and Yuan, B. (1995). Fuzzy Sets and Fuzzy Logic: Theory and Applications (1st edition.). Upper Saddle River, N. J: Prentice Hall.

Koskela, L. and Howell, G. A. (2002). The theory of project management-problem and opportunity. Unpublished Research Note, VTT Technical Research Centre of Finland.

Krugman, H. E. (1966). White and Negro Responses to Package Designs. Journal of Marketing Research, 3, 199-200.

Kutsch, E. and Hall, M. (2005). Intervening conditions on the management of project risk: Dealing with uncertainty in information technology projects. International Journal of Project Management, 23, 591-599.

Latour, B. (1987). Science in Action: How to Follow Scientists and Engineers Through Society. Milton Keynes: Open University Press.

Latour, B. (2005). Reassembling the Social, New York, NY, Oxford University Press

Latour, B. (2007). Reassembling the Social: An Introduction to Actor-Network-Theory (Clarendon Lectures in Management Studies), Oxford University Press, Oxford.

Leach, L. (1999). Critical Chain project management improves project performance. Project Management Journal, 30(2), 39-51.

Lehtimäki, A. K. (1987). An approach for solving decision problems of master scheduling by utilizing theory of fuzzy sets. International Journal of Production Research, 25(12), 1781.

Leybourne, S. (2007). The changing bias of project management research: A consideration of the literatures and an application of extant theory. Project Management Journal, 38 (1), 61-73.

Lin, P., Lee, W., and Lee, M. (2009). Exploring problems and undesired effects in the construction development process: The case of a small- to medium-sized developer in Taiwan. Journal of Construction Engineering and Management, 135(7), 560-569.

Linde, A. and Linderoth, H. (2006). An Actor Network Theory perspective on IT projects. In: Hodgson, D. and Cicmil, S. (Eds.), Making Projects Critical. Palgrave Macmillan, New York, pp. 155-170.

Lingard, H. C., Cooke, T., and Blismas, N. (2012). Designing for construction workers' occupational health and safety: a case study of socio-material complexity. Construction Management and Economics, 30(5), 367-382.

Littau, P., Jujagiri, N. J., and Adlbrecht, G. (2010). 25 years of stakeholder theory in project management literature (1984-2009). Project Management Journal, 41(4), 17-29.

Lorterapong, P. and Moselhi, O. (1996). Project-network analysis using fuzzy sets theory. Journal of Construction Engineering \& Management, 122(4), 308.

Mak, S. W. (1995). Risk analysis in construction: a paradigm shift from a hard to soft approach. Construction Management \& Economics, 13(5), 385.

Maravas, A. and Pantouvakis, J. P. (2012). Project cash flow analysis in the presence of uncertainty in activity duration and cost. International Journal of Project Management, 30(3), 374-384.

March, J. C. (1978). Bounded rationality, ambiguity, and the engineering of choice. Bell Journal of Economics, 9, 578-608.

Mitchell, R., Agle, B., and Wood, D. (1997). Toward a theory of stakeholder identification and salience: defining the principle of who and what really counts. Academy of Management Review, 22(4), 853-866.

Morris, P., Jamieson, A., and Shepherd, M. (2006). Research updating the APM body of knowledge (4th ed.). International Journal of Project Management, 24, 461-473.

Moselhi, O. (1995). Pricing Construction Risk: Fuzzy Set Application. Journal of Construction Engineering \& Management, 121(1), 163.

Pan, N. F. (2006). Evaluation of building performance using fuzzy FTA. Construction Management \& Economics, 24(12), 1241-1252.

Nicholas, J., Holt, G. D., and Mihsein, M. (2000). Contractor financial credit limits; their derivation and implications for materials suppliers. Construction Management and Economic, 18, 535-545.

Nieto-Morote, A. and Ruz-Vila, F. (2011). A fuzzy approach to construction project risk assessment. International Journal of Project Management, 29(2), 220-231.

Nieto-Morote, A. and Ruz-Vila, F. (2012). A fuzzy multicriteria decision-making model for construction contractor prequalification. Automation in Construction, 25, 8-19.

Okoroh, M. I. and Torrance, V. b. (1999). A model for subcontractor selection in refurbishment projects. Construction Management \& Economics, 17(3), 315327.

Parkin, J. (1996). Organizational decision making and the project manager. International Journal of Project Management, 14 (5), 257-263. 
Parkinson, C. (1957). Parkinson's Law. Cambridge: The Riverside Press.

Phillips, R., Freeman, R., and Wicks, A. (2003). What stakeholder theory is not. Business Ethics Quarterly, 13(4), 479-502.

Piney, C. (2003). Applying utility theory to risk management. Project Management Journal, 34(3), 2631.

Plebankiewicz, E. (2012). A fuzzy sets based contractor prequalification procedure. Automation in Construction, 22, 433-443.

Project Management Institute (1999).The Future of Project Management. Newtown Square, Pa: Project Management Institute.

Pollack, J., Costello, K., and Sankaran, S. (2013). Applying actor-network theory as a sense-making framework for complex organisational change programs. International Journal of Project Management, 31, 1118-1128.

Project Management Institute. (2013). A guide to the Project management Body of Knowledge: (PMBOK® guide). Newtown Square, Pa: Project management institute.

Rand, G. (2000). Critical chain: the theory of constraints applied to project management. International Journal of Project Management, 18, 173-177.

Read, D. R. (1964). A Quantitative approach to the comparative assessment of taste quality in the confectionery industry. Biometrics, 20, 143-155.

Ronen, B. and Starr, M. (1990). Synchronized manufacturing as in OPT: From practice to theory. Computers and Industrial Engineering, 18(8), 585600.

Sachs, T. and Tiong, R. L. K. (2009). Quantifying Qualitative Information on Risks: Development of the QQIR Method. Journal of Construction Engineering \& Management, 135(1), 56-71.

Sage, D., Dainty, A., and Brookes, N. (2011). How actornetwork theories can help in understanding project complexities. International Journal of Managing Projects in Business, 4(2), 274-293.

Sauer, C. and Reich, B. H. (2007). What do we want from a theory of project management? A response to Rodney Turner. International Journal of Project Management, 25(1), 1-2.

Shenhar, A. J. and Dvir, D. (1996). Toward a typological theory of project management. Research Policy, 25(4), 607-632.

Shi, Q. and Blomquist, T. (2012). A new approach for project scheduling using fuzzy dependency structure matrix. International Journal of Project Management, 30(4), 503-510.

Shou, Y. and Yeo, K. (2000). Estimation of project buffers in critical chain project management. IEEE ICIMT, 162-167.

Shu, S. L. and Shih, K. (2009). A framework of critical resource chain for project schedule analysis. Construction Management and Economics, 27, 857869.

Singh, D. and Tiong, R. L. K. (2005). A Fuzzy Decision Framework for Contractor Selection. Journal of Construction Engineering \& Management, 131(1), $62-70$.
Smithson, M. (1982). Applications of fuzzy set concepts to behavioral sciences. Mathematical Social Sciences, 2(3), 257-274.

Leu, S. S. and Chen, A. T. (2001). A GA-based fuzzy optimal model for construction time-cost trade-off. International Journal of Project Management, 19(1), 47.

Steyn, H. (2000). An investigation into the fundamentals of critical chain project scheduling. International Journal of Project Management, 19, 363-369.

Steyn, H. (2002). Project management applications of the theory of constraints beyond critical chain scheduling. International Journal of Project Management, 20(1), 75-80.

Sutterfield, J., Friday, S. S., and Shivers, B. S. (2006). A case study of project and stakeholder management failures: lessons learned. Project Management Journal, 37(2), 26-35.

Trietsch, D. (2005). Why a critical path by any other name would smell less sweet? Project Management Journal, 36(1), 27-36.

Turner, J. R. (2006). Towards a theory of project management: The nature of the functions of project management. International Journal of Project Management, 24(4), 277-279.

Tseng, T. L., Huang, C. C., Chu, H. W., and Gung, R. R. (2004). Novel approach to multi-functional project team formation. International Journal of Project Management, 22(2), 147-159.

Walker, D., Bourne, L., and Shelley, A. (2008). Influence, stakeholder mapping and visualization. Construction Management and Economics, 26(6), 645-658.

Wang, R. C. and Liang, T. F. (2004). Project management decisions with multiple fuzzy goals. Construction Management \& Economics, 22(10), 1047-1056.

Wang, X. and Huang, J. (2006). The relationships between key stakeholders' project performance and project success: perceptions of Chinese construction supervising engineers. International Journal of Project Management, 24(3), 253-260.

Wang, W. (2002). Sim-Utility: Model for project ceiling price determination. Journal of construction engineering and management, 128(1), 76-84.

Watson, K., Blackstone, J., and Gardiner, S. (2007). The evolution of a management philosophy: the theory of constraints. Journal of Operations Management, 25(2), 387-402.

Wei, C., Liu, P., and Tsai, Y. (2002). Resourceconstrained project management using enhanced theory of constraints. International Journal of Project Management, 20(7), 561-567.

Wei, C. C. and Wang, M. J. J. (2004). A comprehensive framework for selecting an ERP system. International Journal of Project Management, 22(2), 161-169.

Wei, C. C., Liang, G. S., and Wang, M. J. J. (2007). A comprehensive supply chain management project selection framework under fuzzy environment. International Journal of Project Management, 25(6), 627-636.

Wiest, J. (1964). Some properties of schedules for large projects with limited resources. Operations Research, 12, 395-418. 
42 Johnson, N., Creasy, T., and Fan, Y.

Williams, T. M. (2004). Assessing and building on the underlying theory of project management in the light of badly over-run projects.

Winter, M., Smith, C., Morris, P., and Cicmil, S. (2006). Directions for future research in project management: The main findings of a UK government-funded research network. International Journal of Project Management, 24, 638-649.

Wong, K. C. and So, A. T. P. (1995). A fuzzy expert system for contract decision making. Construction Management \& Economics, 13(2), 95.

Xia, B., Chan, A. P. C., and Yeung, J. F. Y. (2011). Developing a fuzzy multicriteria decision-making model for selecting design-build operational variations. Journal of Construction Engineering \& Management, 137(12), 1176-1184.

Yang, Y. Q., Wang, S. Q., Dulaimi, M., and Low, S. P. (2003). A fuzzy quality function deployment system for buildable design decision-makings. Automation in Construction, 12(4), 381.

Zadeh, L. A. (1965). Fuzzy sets. Information and Control, 8(3), 338-353.

Zahraie, B. and Tavakolan, M. (2009). Stochastic timecost-resource utilization optimization using nondominated sorting genetic algorithm and discrete fuzzy sets. Journal of Construction Engineering \& Management, 135(11), 1162-1171.

Zhao, X., Hwang, B. G., and Low, S. P. (2013). Developing fuzzy enterprise risk management maturity model for construction firms. Journal of Construction Engineering \& Management, 139(9), 1179-1189.

Zheng, D. X. M. and Ng, S. T. (2005). Stochastic timecost optimization model incorporating fuzzy sets theory and nonreplaceable front. Journal of Construction Engineering \& Management, 131(2), 176-186.

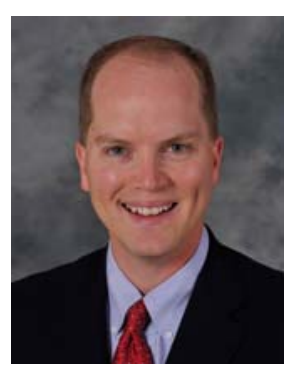

Dr. Nathan Johnson is an Assistant Professor at Western Carolina University in the School of Economics, Management, and Project Management and is a certified Project Management Professional. He obtained his Ph.D. in Business Administration from Washington State University. His research interests include enterprise mobile readiness, mobile information technology, healthcare information systems, and project management. Before entering academia, he was an active duty medical officer in the US Air Force serving in hospital administration and information systems. His research has appeared in journals such as Journal of Information Technology Case and Application Research, International Journal of Information, Business, and Management, and Supervision and at conferences such as Americas Conference on Information Systems and the Project Management Institute's Research and Education Conference.

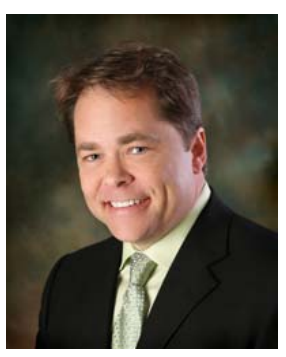

Dr. Todd Creasy is an Associate Professor at Western Carolina University in the School of Economics, Management, and Project Management at Western Carolina University, a campus of the University of North Carolina. Dr. Creasy has published several scholarly journal articles, published in trade journals, given numerous conference presentations and appeared on the Fox Business Network. His consulting firm specializes in project management and Lean Six Sigma training/project execution in various industries to include: healthcare, mining, manufacturing, transportation and construction. Dr. Creasy's academic qualifications include a doctorate degree from Case Western Reserve University; Master of Science in Finance, a MBA and BSBA in industrial engineering from the University of Memphis. Further, Dr. Creasy is a certified Six Sigma Master Black Belt from the Juran Institute and Lean practices trainer and consultant.

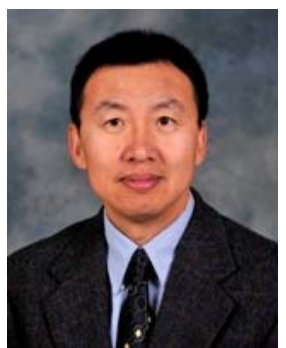

Dr. Yang Fan is an Associate Professor at Western Carolina University in the School of Economics, Management, and Project Management at Western Carolina University and is a certified Project Management Professional. He has taught project management since 2008. His current research interests include project stakeholder management, organizational behavior, and international project management. Dr. Fan has published 13 scholarly journal articles and co-authored 3 books. He served on the board of PMI Quality Community of Practice (CoP) from 2010 to 2012, and on the board of PMI Quality Management Special Interest Group (SIG) from 2009 to 2010. Dr. Fan has served over 25 years in planning, business management, and education positions. Prior to joining Western Carolina University, he worked in China, France and Saudi Arabia as project manager, researcher and professor. 
Recent Trends in Theory Use and Application within the Project Management Discipline 43

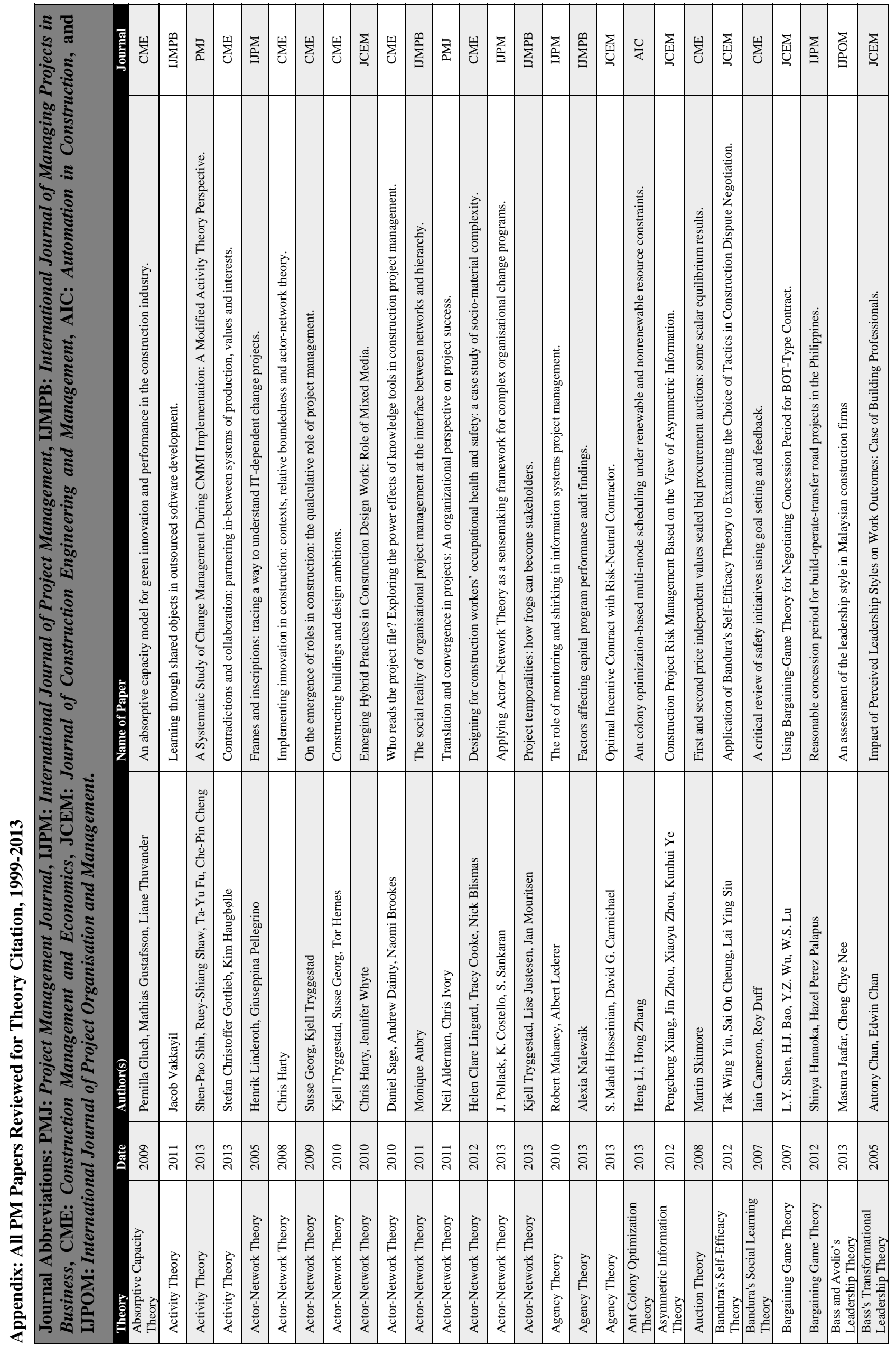


44 Johnson, N., Creasy, T., and Fan, Y.

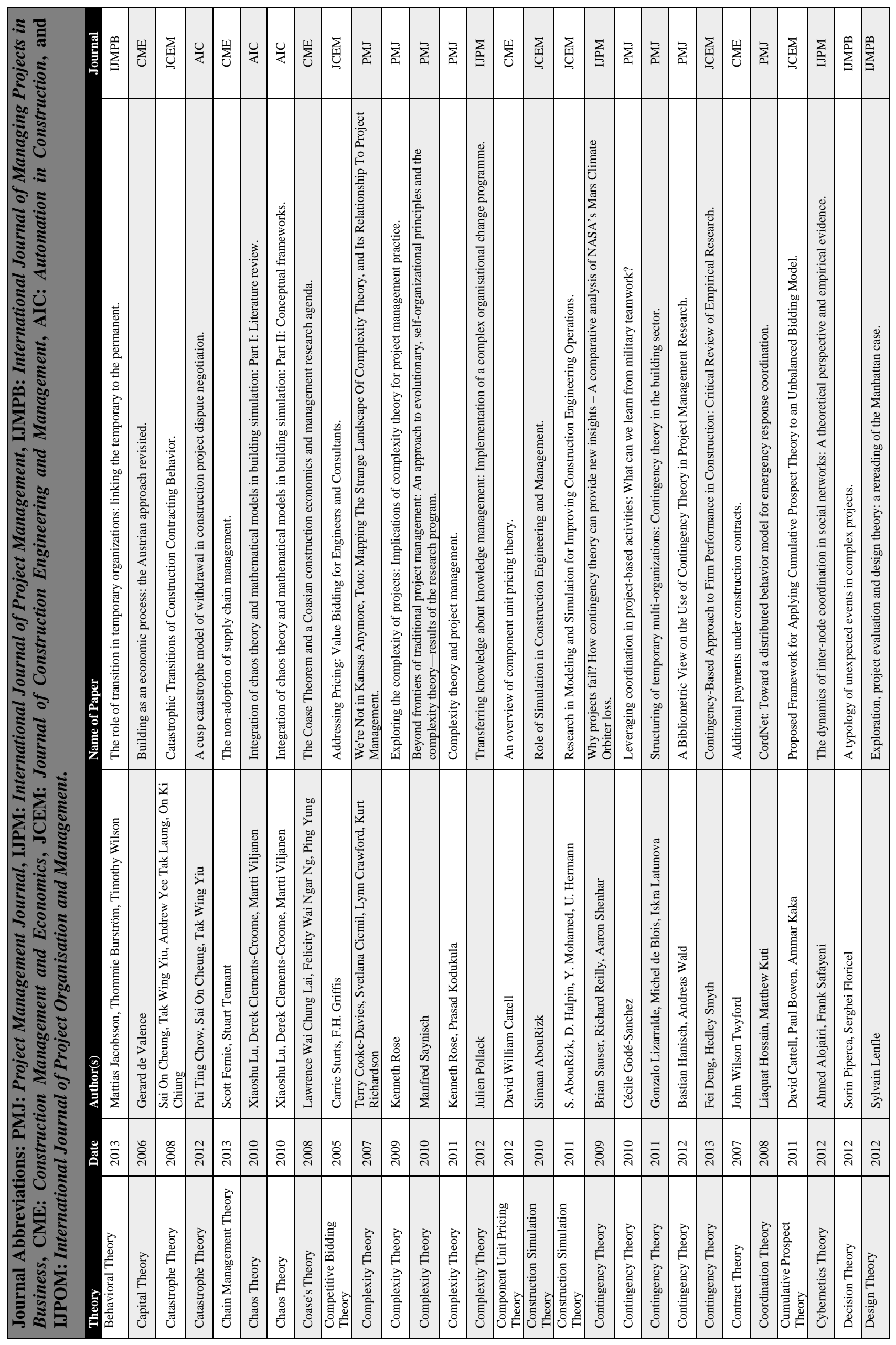


Recent Trends in Theory Use and Application within the Project Management Discipline 45

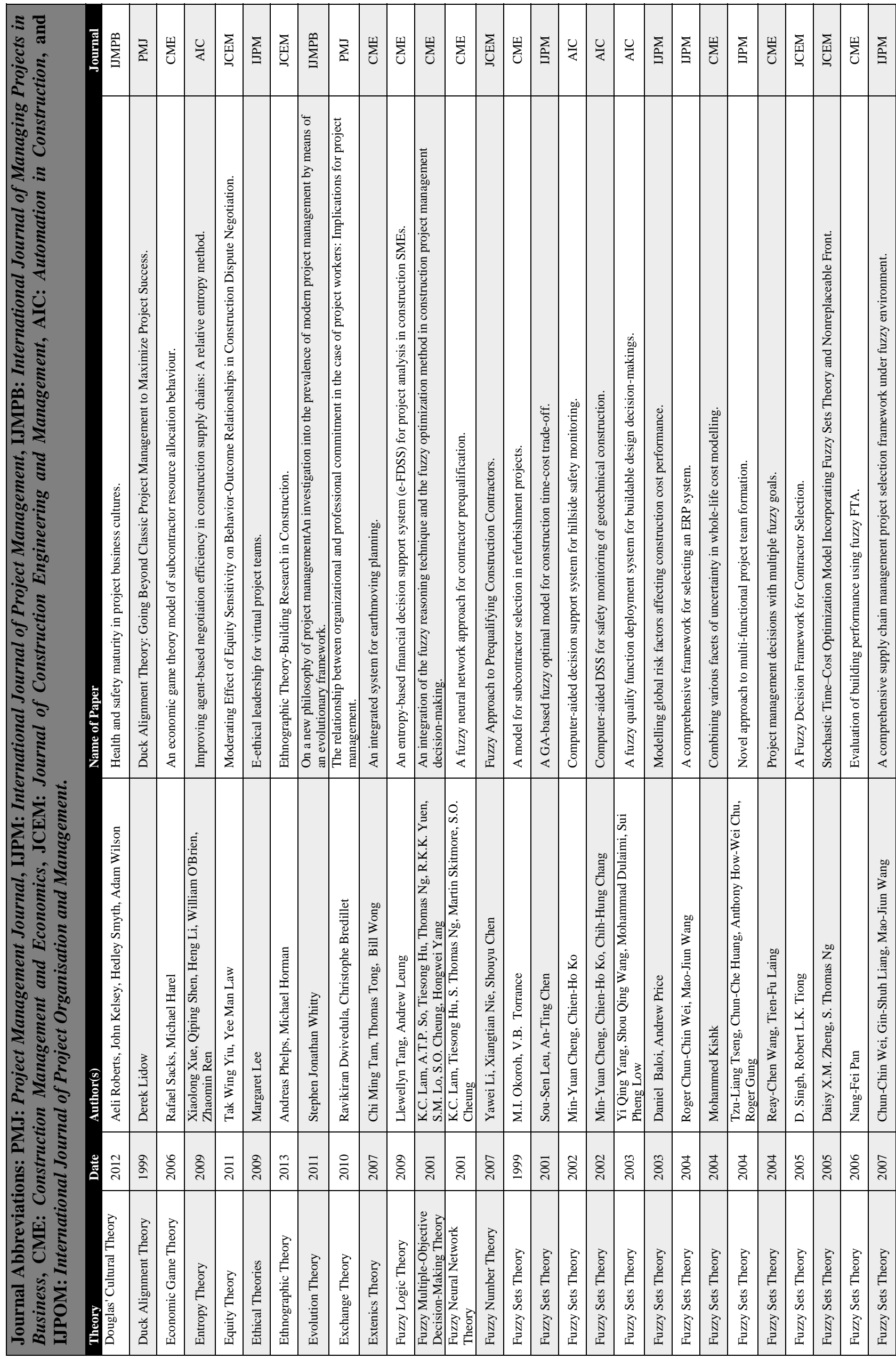


46 Johnson, N., Creasy, T., and Fan, Y.

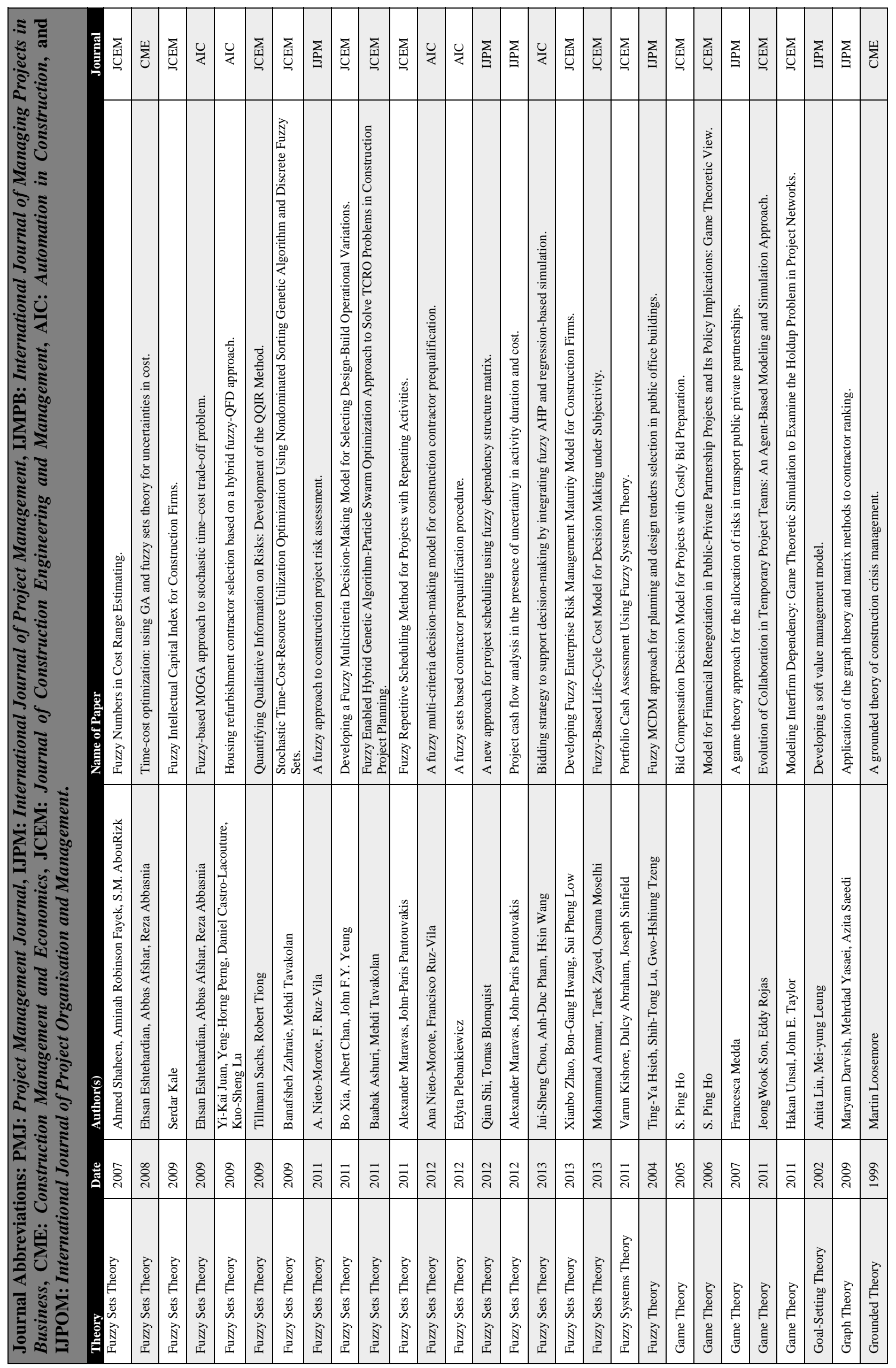


Recent Trends in Theory Use and Application within the Project Management Discipline 47

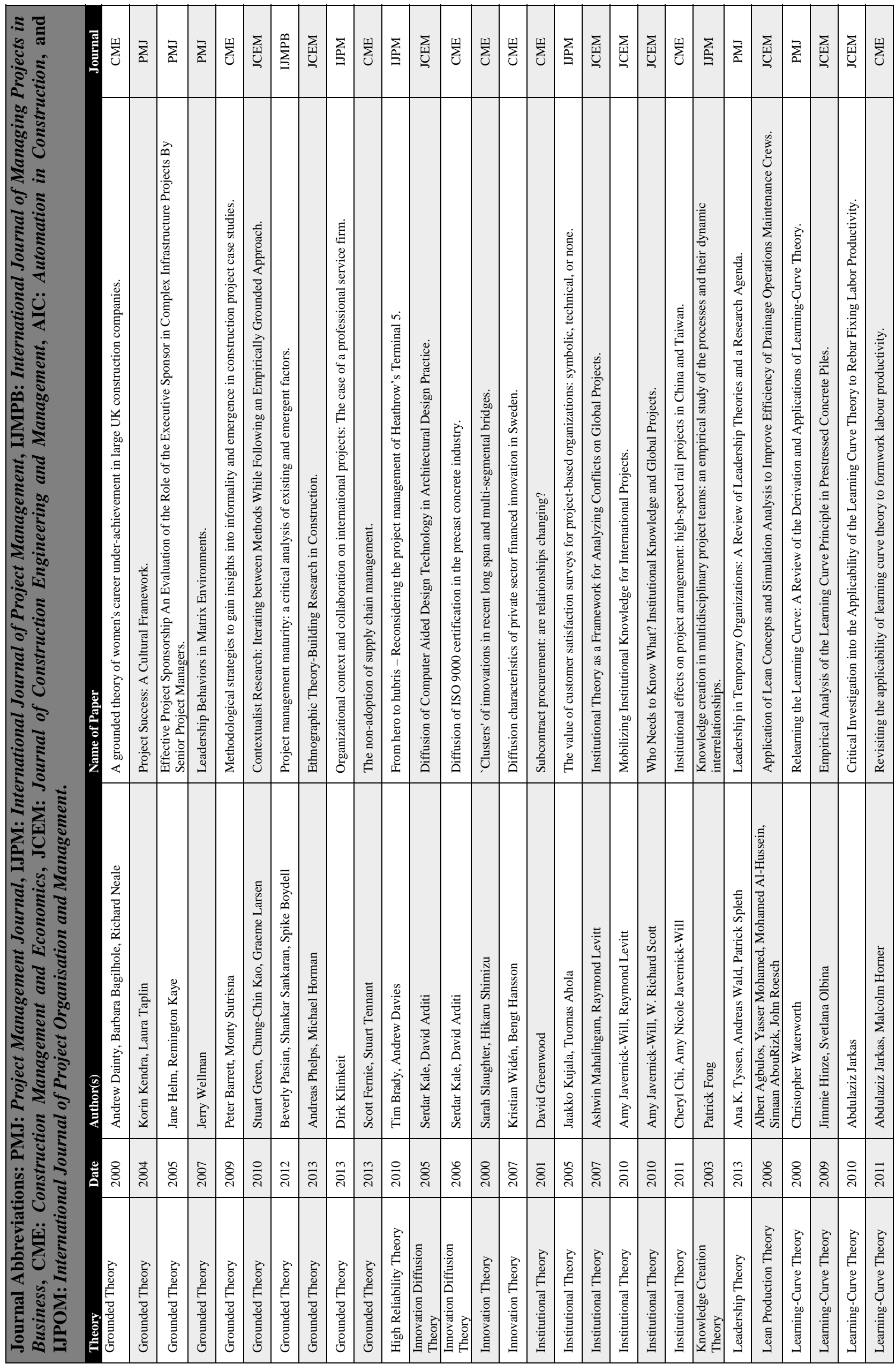


48 Johnson, N., Creasy, T., and Fan, Y.

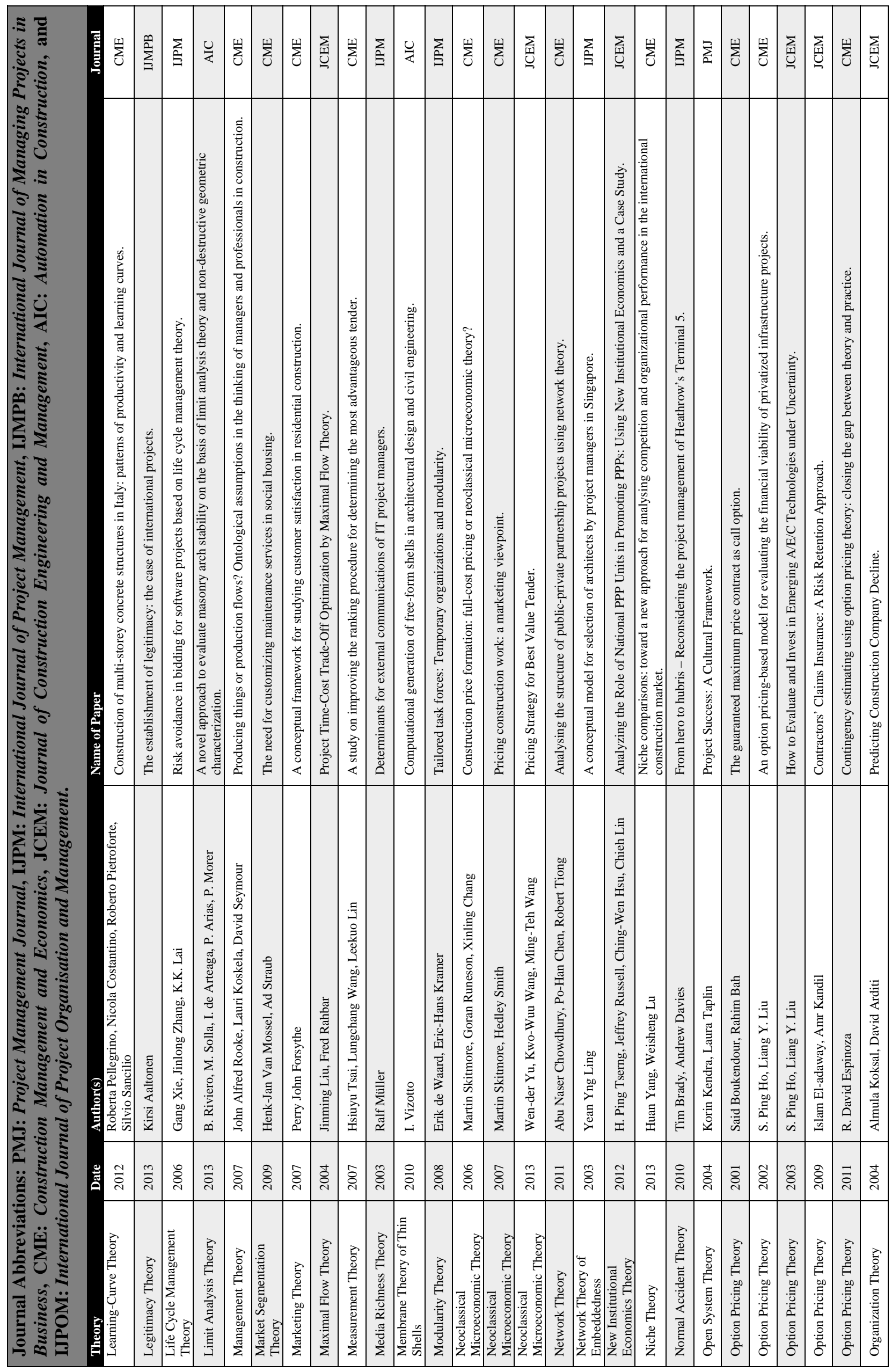




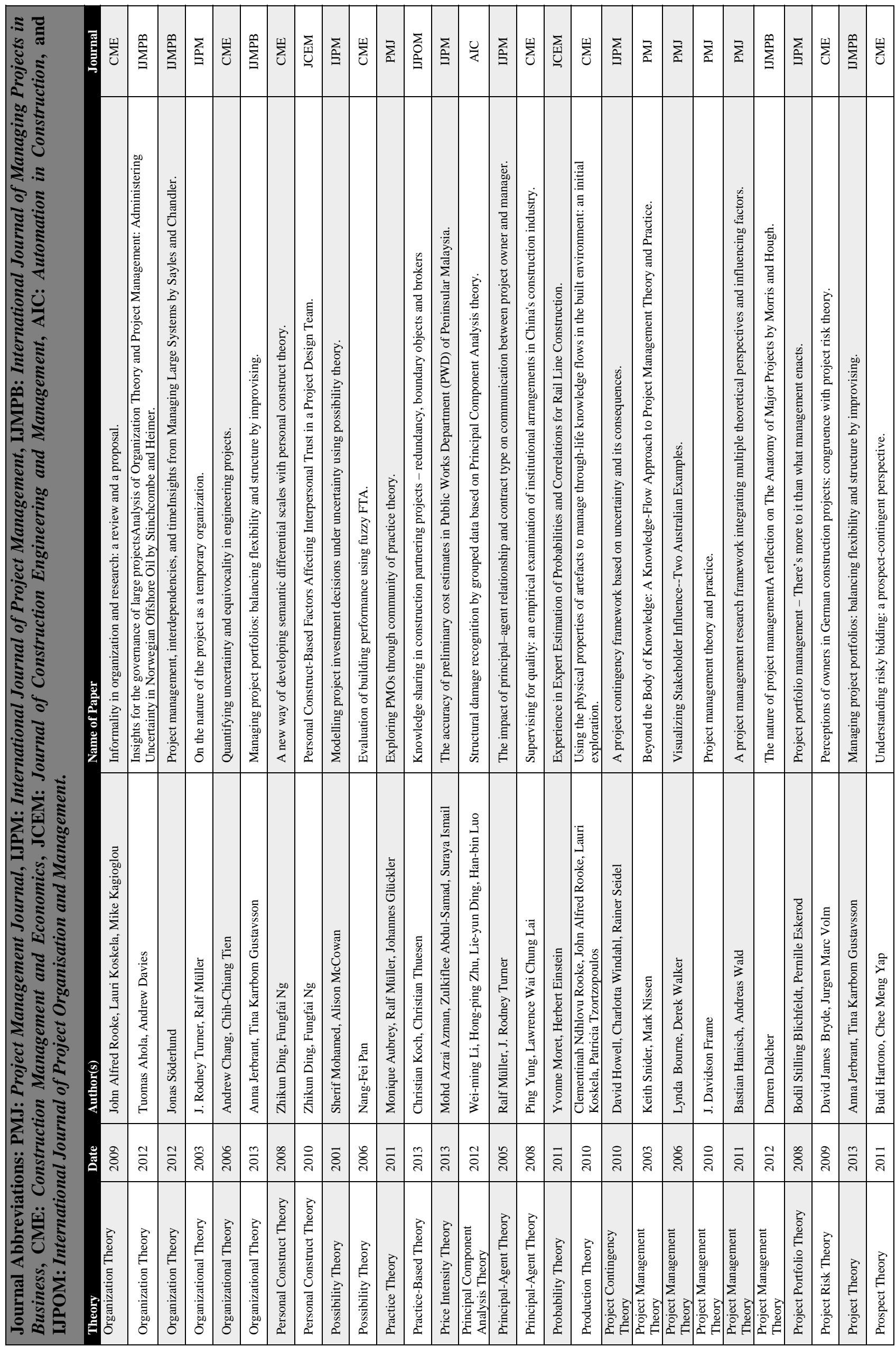




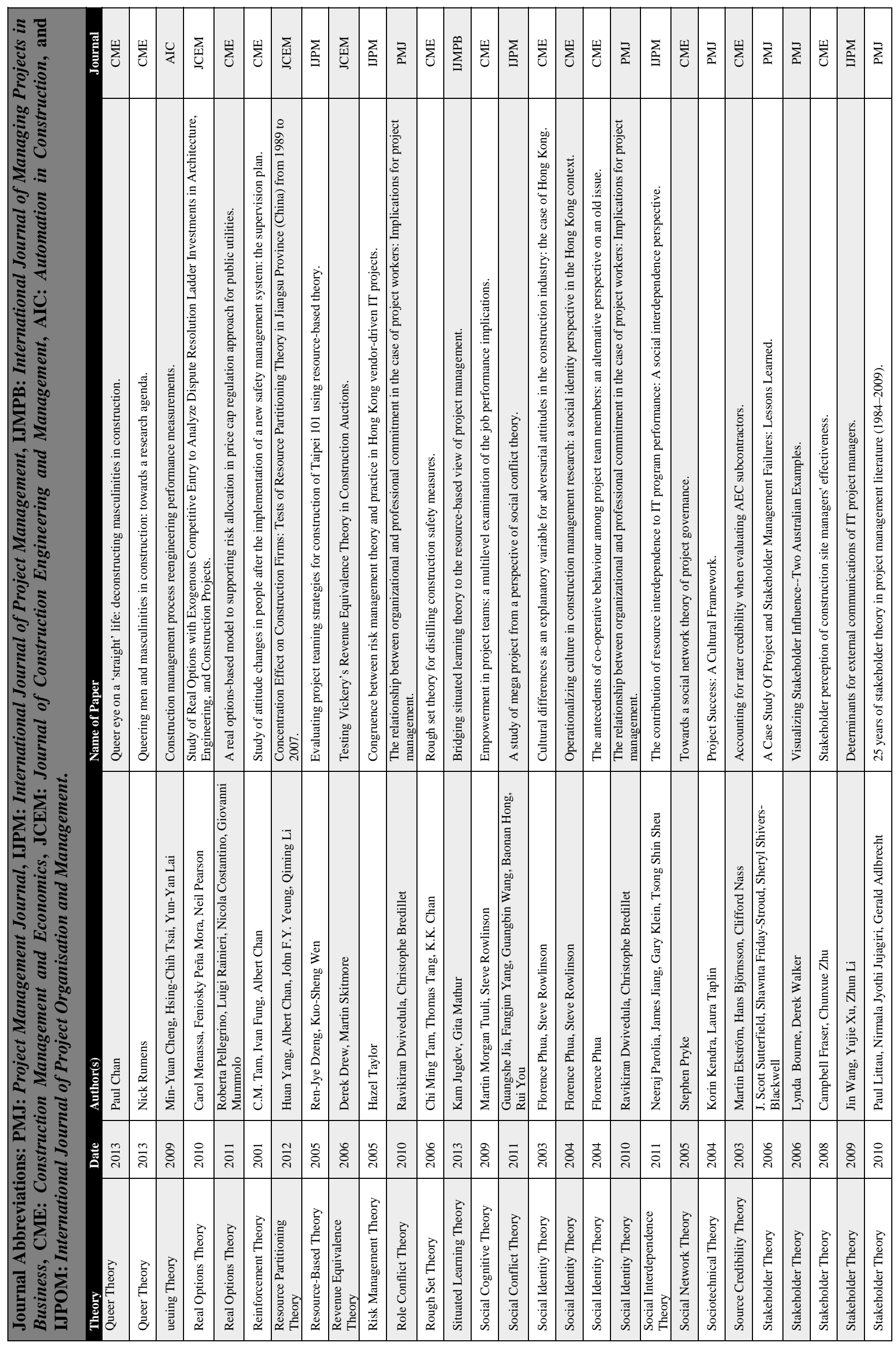


Recent Trends in Theory Use and Application within the Project Management Discipline 51

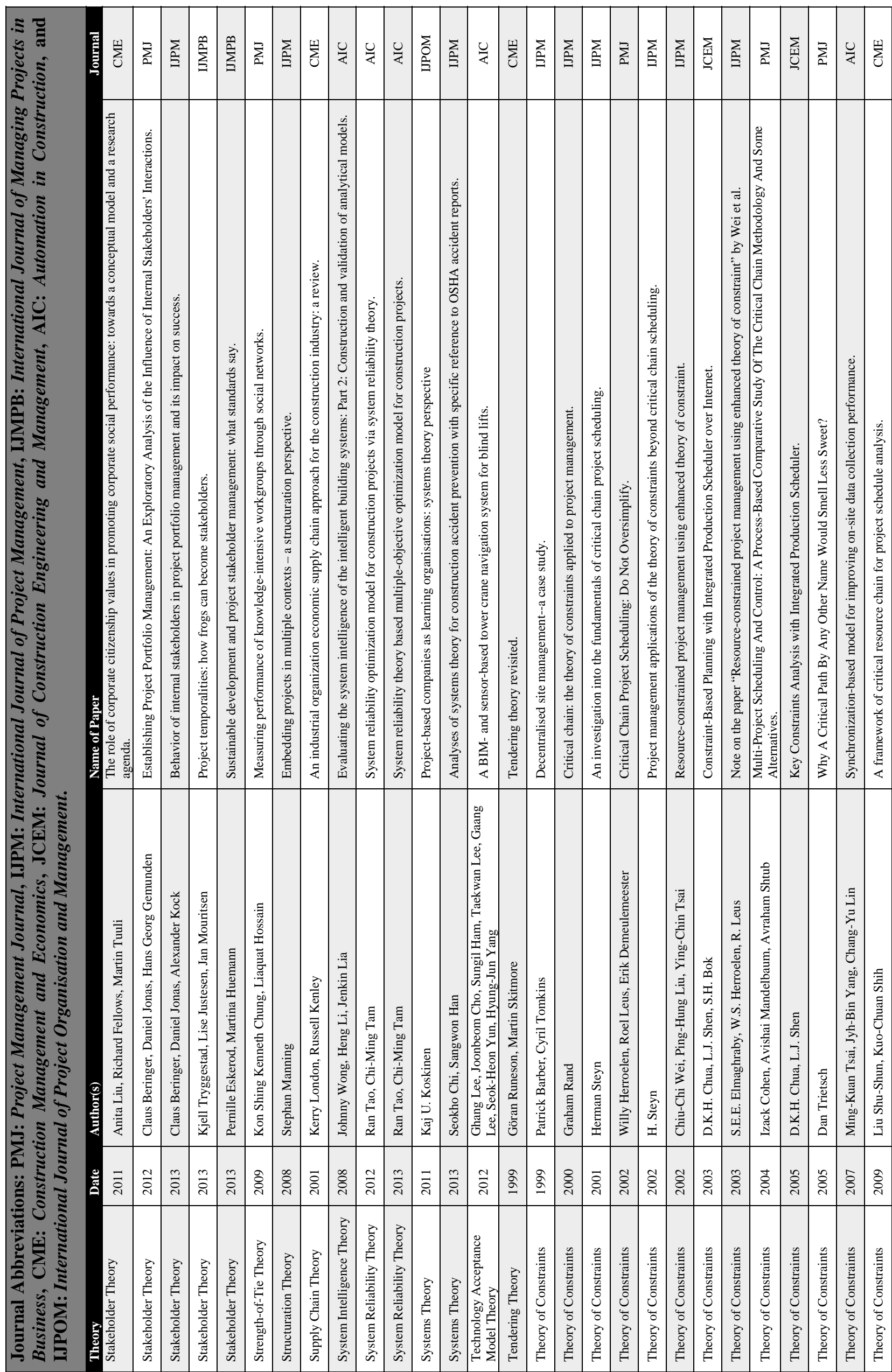




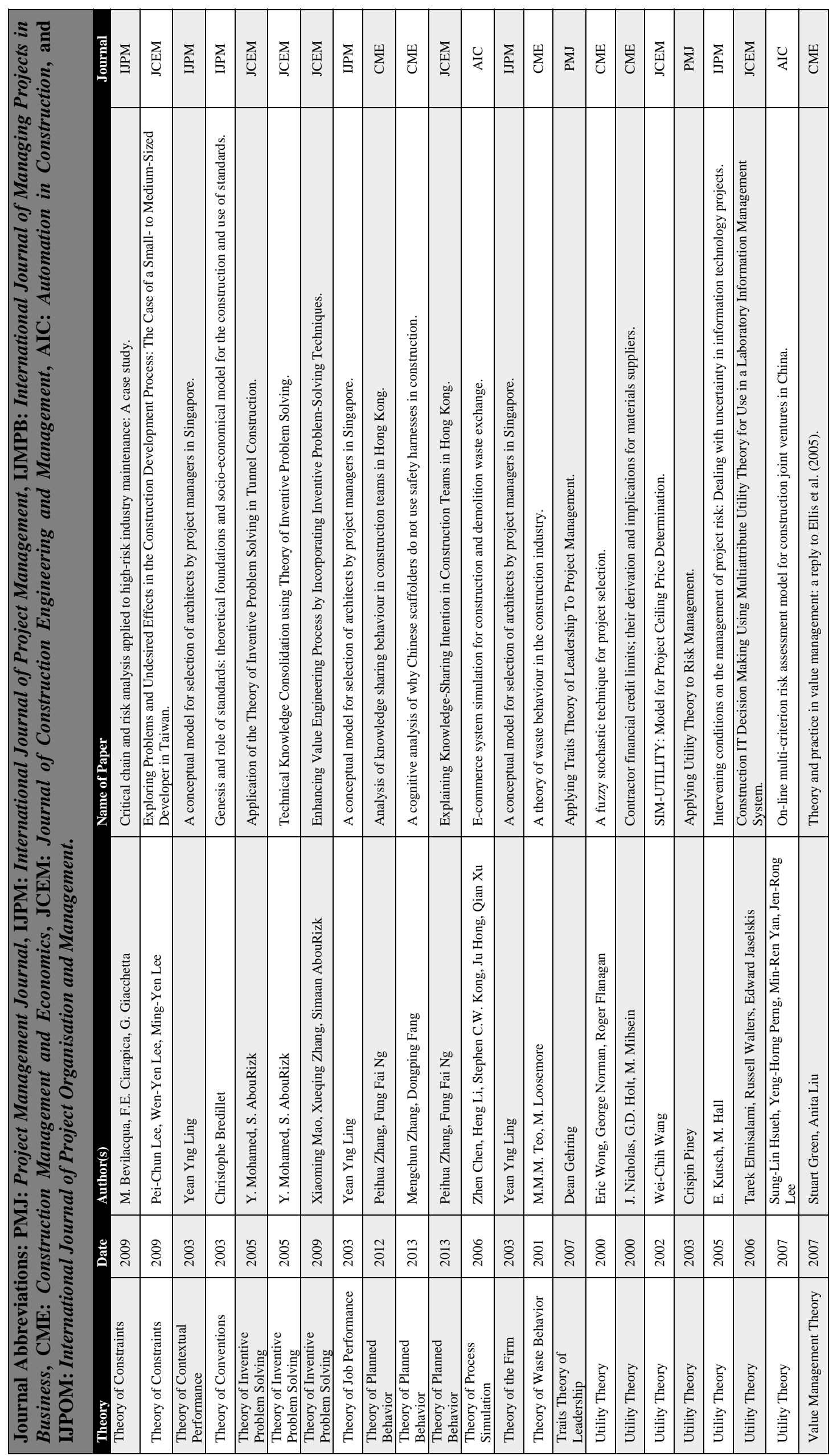

